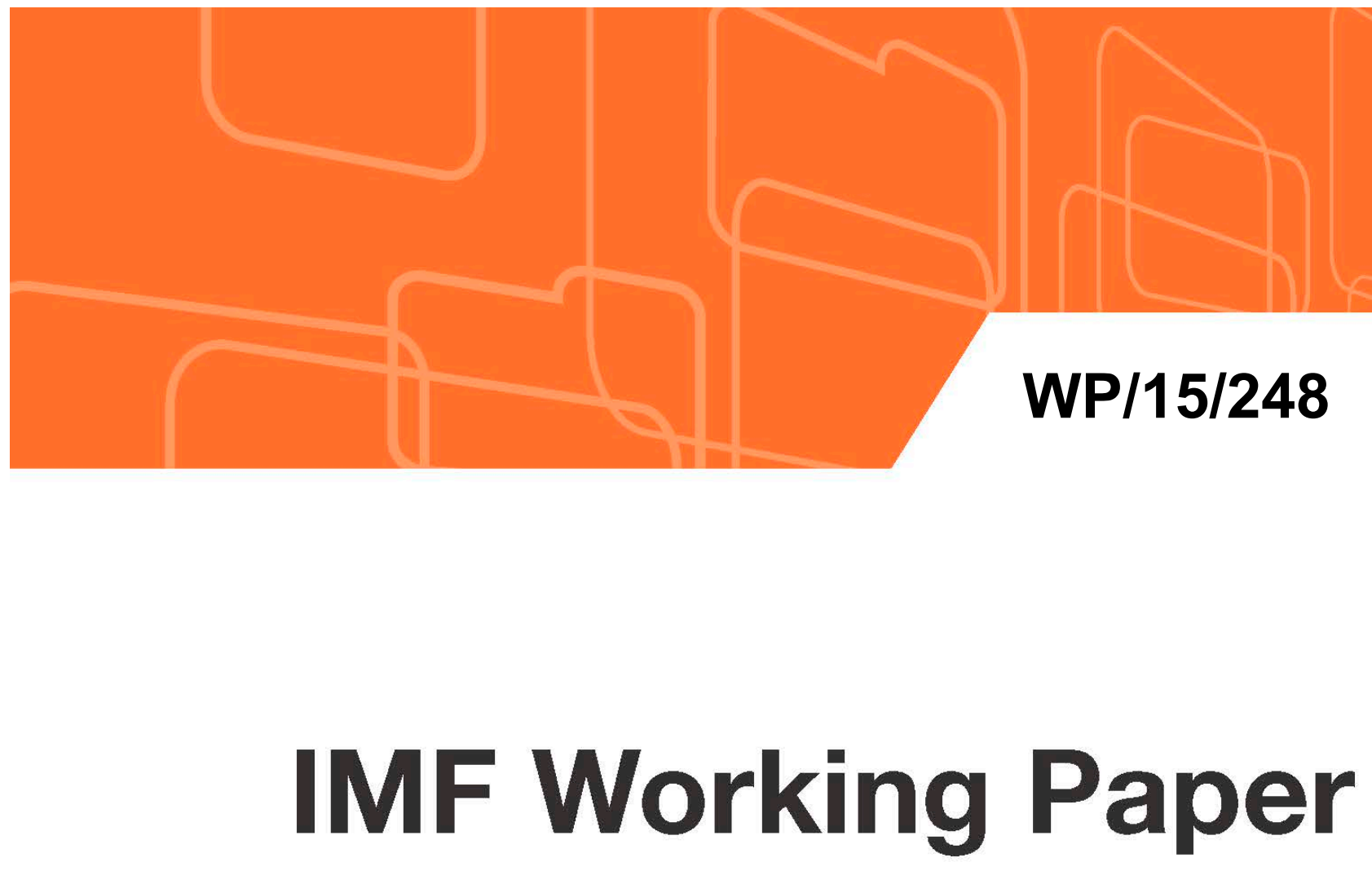

\title{
How Do Public Debt Cycles Interact with Financial Cycles?
}

\author{
by Tigran Poghosyan
}

IMF Working Papers describe research in progress by the author(s) and are published to elicit comments and to encourage debate. The views expressed in IMF Working Papers are those of the author(s) and do not necessarily represent the views of the IMF, its Executive Board, or IMF management. 


\title{
IMF Working Paper
}

Fiscal Affairs Department

\section{How Do Public Debt Cycles Interact with Financial Cycles? \\ Prepared by Tigran Poghosyan ${ }^{1}$}

Authorized for distribution by Bernardin Akitoby

November 2015

\begin{abstract}
IMF Working Papers describe research in progress by the author(s) and are published to elicit comments and to encourage debate. The views expressed in IMF Working Papers are those of the author(s) and do not necessarily represent the views of the IMF, its Executive Board, or IMF management.
\end{abstract}

\begin{abstract}
We employ a duration model to study determinants of public debt cycles in 57 advanced and emerging economies over the 1960-2014 period, with a particular focus on the impact of financial cycles. The results suggest that the association between financial and debt cycles is asymmetric. Debt expansions preceded by overheating in credit and financial markets tend to last longer than other expansions, but there is no significant association between financial cycles and debt contractions. There is strong evidence of duration dependence in both phases of the cycle, with the likelihood of expansions and contractions to end increasing with the length of their respective spells. Higher initial level of debt increases the spell of contractions (persistence of adjustment effort hypothesis) and reduces the spell of expansions (debt sustainability hypothesis). This result is robust to the inclusion of global factors, openness, political stability, and debt crisis indicators as additional controls.
\end{abstract}

JEL Classification Numbers: E6; C4; H6

Keywords: public debt cycles, credit cycles, asset price cycles, duration analysis

Author's E-Mail Address: tpoghosyan@imf.org.

\footnotetext{
${ }^{1}$ I would like to thank Bernardin Akitoby, Tamim Bayoumi, Julio Escolano, Karina Garcia, Vitor Gaspar, Deniz Igan, Luis Jacome, Carlos Mulas-Granados, Martin Saldias, Damiano Sandri, Abdelhak Senhadji, Cesar Serra, Marzie Taheri Sanjani and seminar participants at IMF's Fiscal Affairs Department for useful comments and suggestions. Macarena Torres Girao provided excellent editorial assistance. The usual disclaimer applies.
} 
Abstract ....1... -

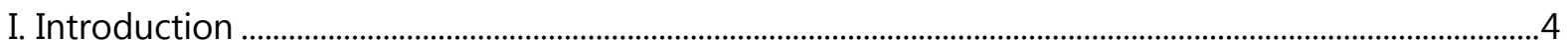

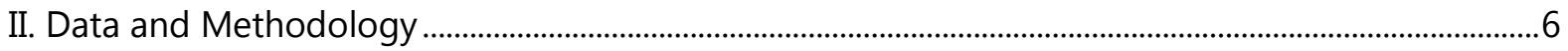

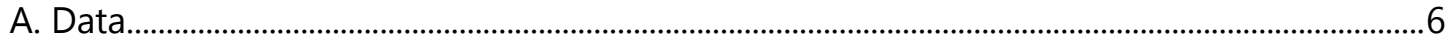

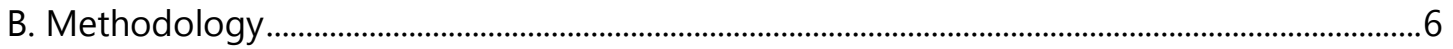

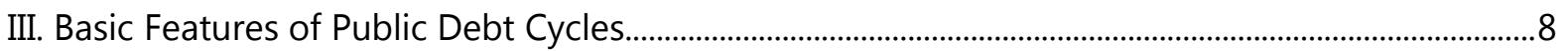

A. Frequency of Public Debt Cycles ................................................................................................

B. Duration, Amplitude, and Slope of Public Debt Cycles............................................................... 8

C. Determinants of Public Debt Dynamics around Expansion/Contraction Episodes..............8

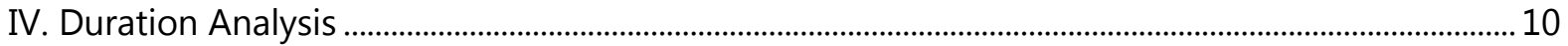

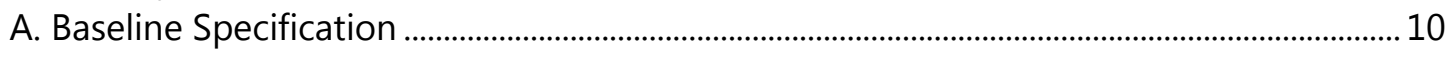

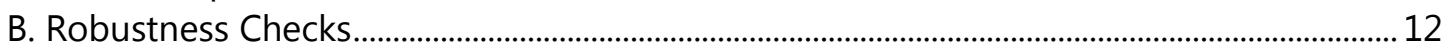

V. Conclusions

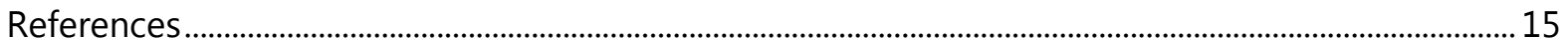

Tables

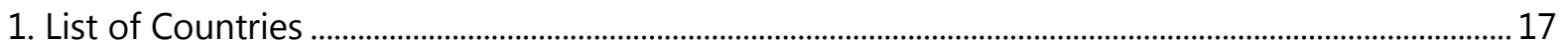

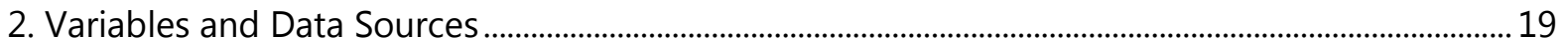

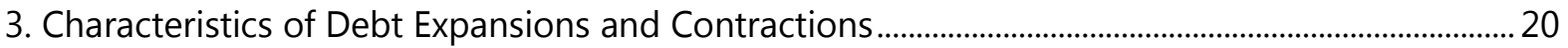

4. Descriptive Statistics of Determinants of Public Debt Dynamics ........................................................... 21

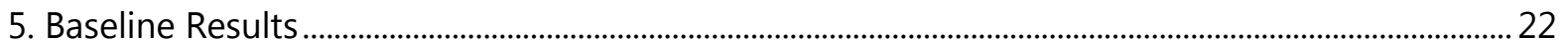

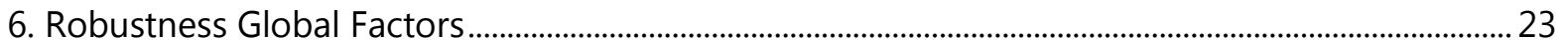

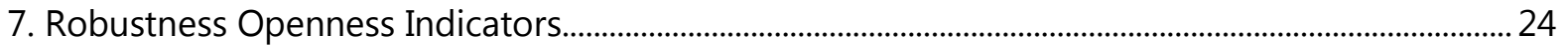

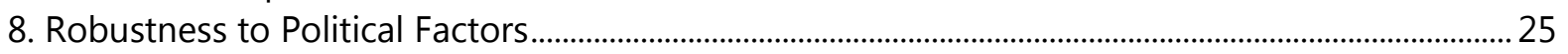

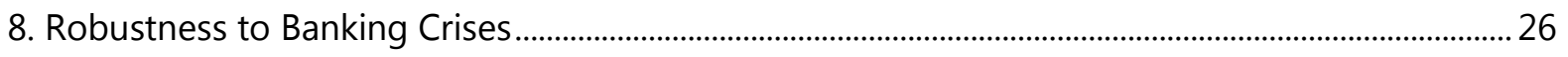

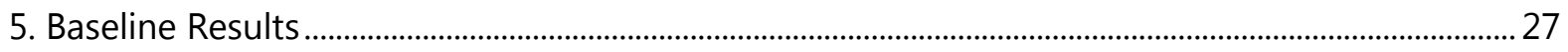

Figures

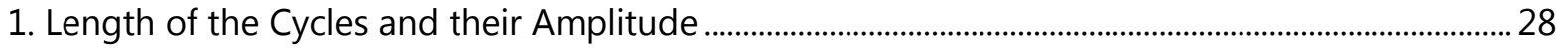

2. Dynamics of Debt and its Determinants around Expansion Episodes ................................................. 29

3. Dynamics of Debt and its Determinants around Contraction Episodes............................................... 31

4. Non-Parametric Impact of Financial Cycles on the Duration of Debt Expansions and 


\section{INTRODUCTION}

The linkages between the financial sector and real economy have received much attention in the literature over the past few decades. The global financial crisis has further reinforced the policy debate on the implications of financial market gyrations on output cycles (Borio, 2014). Given the close association between the financial markets, real economy and public finances, public debt cycles are also expected to be influenced (IMF, 2015; Jorda et al., 2015). While there is growing evidence on the importance of financial shocks for fiscal accounts (Afonso et al., 2011; Benetrix and Lane, 2013; Budina et al., 2015; Liu et al., 2015), empirical analysis of public debt cycles and their association with financial cycles has not been performed systematically in the past. The purpose of this paper is to contribute to the growing literature on the financial markets-fiscal policy nexus and analyze the main features of public debt cycles, with a specific focus on the impact of boom and bust in the financial markets.

An extensive theoretical literature studies the interaction between macroeconomic and financial market developments. Many theoretical models emphasize the lasting impact of movements in financial variables, such as the external finance premium (Bernanke et al., 1999) and collateral prices (Kiyotaki and Moore, 1997), on output. These models predict that in the presence of financial frictions, movements in financial variables can amplify wealth and substitution effects through financial accelerator and related mechanisms, ultimately influencing aggregate business cycles.

In a series of recent empirical papers, Claessens et al. (2009, 2012, and 2014) provide evidence supporting this theoretical prediction. Using duration model on a sample of advanced and emerging economies starting from 1960s, they show that recessions associated with financial disruptions, such as house price, equity price, and credit busts, tend to be longer and deeper than other recessions. Conversely, recoveries associated with rapid growth in asset prices and credit are stronger, suggesting a symmetric relationship between financial and business cycles. Other recent papers also provided empirical evidence on the relationship between credit and output (Helbling et al., 2011), relative length of financial and business cycles (Drehmann et al., 2012), comovements between public and private debt cycles (Jorda et al., 2015) and financial and macro-fiscal variables surrounding crises (Reinhart and Rogoff, 2009; IMF, 2015).

Despite the close association between financial markets, real economy and public finances, linkages between financial and public debt cycles in the context of a duration framework were not studied systematically in the past. Some studies employed a regime-switching VAR model to analyze the impact of financial shocks on the dynamics of public debt and found evidence of asymmetry: while public debt increases significantly in response to a negative financial shock, it declines only slightly and insignificantly in response to a positive financial shock (Afonso et al., 2011; Budina et al., 2015). The only duration study we are aware of that analyzes public debt cycles is Baldacci et al. (2012) ${ }^{2}$, but that paper focuses only on one phase of the cycle - debt contractions - and does not assess the impact of financial cycles. Using data on advanced and

\footnotetext{
2 The earlier version of the paper was published as an IMF working paper (Baldacci et al., 2010).
} 
emerging economies over 1980-2010, the authors analyze the impact of adjustment mix factors on the success of fiscal consolidation and find that expenditure-driven consolidations are key for reducing the length of consolidation spells, but revenue-driven adjustment are more effective when adjustment needs are large. ${ }^{3}$

Other duration studies in the public finance literature analyze drivers of successful fiscal consolidations (Von Hagen and Strauch, 2001; Von Hagen et al., 2002; Gupta et al., 2005; Maroto and Mulas-Granados, 2008). In these studies, fiscal consolidation is defined as a reduction of government deficit below a certain threshold. Consolidation is defined as successful if after reduction, deficit is maintained at a low level for a certain period of time. These studies find that the initial level of debt increases the consolidation spell, indicating a greater consolidation persistence effort. The quality of adjustment also matters, with expenditure-driven consolidations having more lasting impact than revenue-driven consolidations. Other determinants of consolidation spells include political stability, openness, and global economic environment.

However, these studies do no analyze both phases of debt cycles explicitly, as well as their interaction with financial cycles. Dynamics of debt-to-GDP ratio, a widely used measure of fiscal health, can be influenced by financial cycles through both numerator and denominator effects (IMF, 2015). The impact of financial cycles on the output (denominator) has been already established in the literature mentioned above. The impact of financial cycle on the nominal debt (numerator) can be direct and indirect (Budina et al., 2015; IMF, 2015). The direct impact comes from the need to rescue banks following banking crises that are often preceded by credit booms (Dell'Arricia et al., 2012) and asset buildups (Crowe et al., 2011). The indirect impact is channeled through the economy. For instance, financial downturns result in higher risk premia, disruption of supply of credit, reduction of consumption and investment, squeeze in aggregate demand, which in turn leads to a permanent reduction of revenues and consequent increase in public deficits and debt (Liu et al., 2015; IMF, 2015).

Our study contributes to the literature by analyzing both phases of public debt cycles (expansions and contractions) for a sample of 57 advanced and emerging economies over the period 1960-2014, with a particular focus on the impact of financial cycles. Using duration model, we find that the relationship between financial and public debt cycles is asymmetric. Debt expansions preceded by overheating in credit and financial markets tend to last longer than other expansions, but there is no significant association between financial cycles and debt contractions. The asymmetric association between financial and public debt cycles supports the "deficit bias" hypothesis (see Debrun et al., 2009 for a survey), according to which governments expand deficits to cushion recessions ("bad times"), but do not rebuild fiscal buffers fully during recoveries ("good times"). The novelty of our result is that it provides first evidence of a "deficit bias" in relation to financial cycles within a duration framework.

We also find strong evidence of duration dependence in both phases of the cycle, with the likelihood of expansions and contractions to end increasing with the length of their respective

\footnotetext{
${ }^{3}$ Consolidation is defined as successful if debt-to-GDP ratio is brought down below 40 (60) percent level in emerging (advanced) economies.
} 
spells. Higher initial level of debt increases the spell of contractions (persistence of adjustment effort hypothesis) and reduces the spell of expansions (debt sustainability hypothesis). The results are robust to the inclusion of global factors, openness, political stability, and debt crisis indicators as additional controls.

The remainder of the paper is structured as follows. Section II describes the dataset and the empirical methodology. Section III demonstrates main characteristics of public debt cycles, including duration, amplitude, and slope of each phase. Section IV presents and discusses the estimation findings. The last section concludes.

\section{Data AND Methodology}

\section{A. Data}

Our database comprises 57 countries (27 advanced and 30 emerging countries) and covers the period 1960-2014. Table 1 lists countries in the sample and Table 2 lists variables and their sources.

For public debt cycles, we use Mauro et al. (2013) annual data and extend it through 2014. The main advantage of this dataset is its length and coverage of both debt stocks and corresponding fiscal balance flows, including their subcomponents. The dataset was hand-collected from different international (WEO, IFS, etc.) and national statistical sources.

For financial cycles, we use quarterly data on equity price, house price, and domestic credit from Liu et al. (2015). These variables were used for analyzing the relationship between financial and business cycles by Claessens et al. (2009, 2012, and 2014). Credit is a natural aggregate to analyze financial cycles as it conveys information on savings and investment and potential risk buildup. We use aggregate claims on the private sector by deposit money banks as a measure of credit. House prices are various indices of house and land prices depending on the source country. Equity prices are individual share prices weighted by their outstanding market values. All financial variables are measured in real terms.

Data on macro and political variables are taken from IMF World Economic Outlook (WEO) and Polity IV databases (Marshall and Jaggers, 2002). Data on banking crises is taken from Laeven and Valencia (2012).

\section{B. Methodology}

\section{Dating public debt and financial cycles}

Following Claessens et al. (2009, 2012, and 2014), we employ the cycle dating algorithm developed by Harding and Pagan (2002). ${ }^{4}$ The algorithm identifies the turning points of economic and financial series by searching for maxima and minima over a given period of time

\footnotetext{
4 This algorithm extends the so-called BB algorithm pioneered by Bry and Boschan (1971).
} 
and selecting pairs of adjacent (locally absolute) maxima and minima. For the annual data on debt-to-GDP ratio ("classical" definition of the cycle), we use the following censoring rules: (i) the duration of a complete cycle to be at least five years; and (ii) the duration of each phase to be at least two years. More specifically:

- $\quad$ a cyclical peak occurs at time $t$ if:

$$
\left\{\left[\left(x_{t}-x_{t-2}\right)>0,\left(x_{t}-x_{t-1}\right)>0\right] \text { and }\left[\left(x_{t+2}-x_{t}\right)<0,\left(x_{t+1}-x_{t}\right)<0\right]\right\}
$$

- $\quad$ a cyclical trough occurs at time $t$ if:

$$
\left\{\left[\left(x_{t}-x_{t-2}\right)<0,\left(x_{t}-x_{t-1}\right)<0\right] \text { and }\left[\left(x_{t+2}-x_{t}\right)>0,\left(x_{t+1}-x_{t}\right)>0\right]\right\}
$$

For the quarterly data on financial variables (equity prices, house prices, and credit), we use the following censoring rules: (i) the duration of a complete cycle to be at least nine quarters; and (ii) the duration of each phase to be at least four quarters. Similar to Claessens et al. $(2009,2012$, 2014), we use quarterly data for financial variables to better capture higher frequency fluctuations. The choice of four quarters for each phase ensures that there are no peaks and troughs recorded simultaneously within the same year, which makes it easier to integrate quarterly peaks and troughs into annual series of debt cycles. The turning points for financial cycles are identified using detrended (HP filter with smoothing parameter 1600) log series to capture cyclical fluctuations of variables around their long-run equilibrium trends (booms and busts).

\section{Characterizing public debt cycles}

A complete public debt cycle comprises two phases (see Picture 1): (i) the expansion phase (from trough to peak); and (ii) the contraction phase (from trough to peak). The main characteristics of cyclical phases are duration, amplitude, and slope. The duration of expansion is the number of years between a trough and the next peak (measured in years). The amplitude of expansion measures the change in debt-to-GDP ratio from trough to the next peak (measured in percent of GDP). The slope of expansion is the ratio of its amplitude to duration (measured in percent of GDP). By analogy, the converse definitions of duration, amplitude, and slope apply to the contraction phase.

Picture 1. Graphical Illustration of Public Debt Cycles

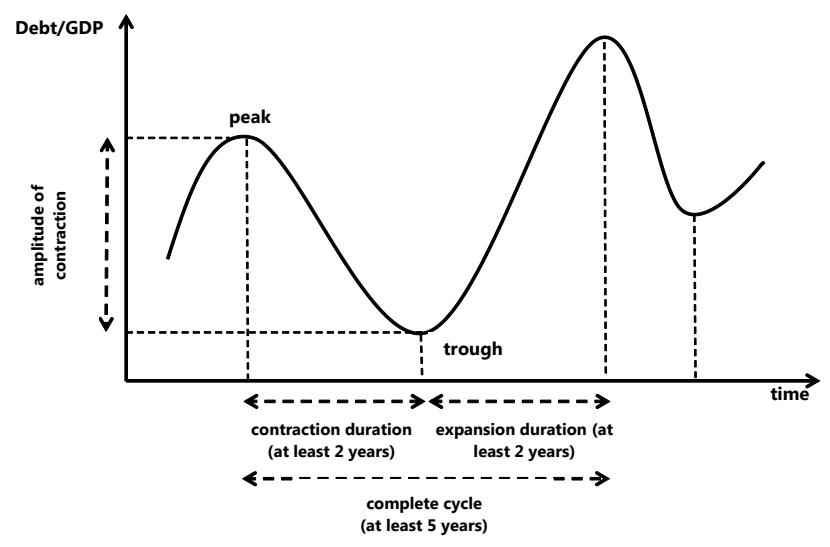




\section{Basic Features of Public Debt Cycles}

\section{A. Frequency of Public Debt Cycles}

Using our methodology, we identify 209 debt expansions and 207 debt contractions in total (Table 3). Of these, 120 expansions and 118 contractions are in emerging economies, and 89 expansions and 89 contractions are in advanced economies. The number of debt contraction episodes is almost twice larger compared to the earlier duration study on debt contractions (Baldacci et al, 2012) given the wider coverage of countries and the longer sample. Moreover, our analysis also covers debt expansion episodes not studied previously.

\section{B. Duration, Amplitude, and Slope of Public Debt Cycles}

The analysis of main characteristics of debt expansions and contractions reveals some interesting patterns. Debt expansions last on average 7.0 years, while debt contractions last 6.1 years in total sample. Debt expansions are lengthier than contractions also when using medians. The median expansion of debt from trough to peak, the expansion amplitude, is 14.5 percent of GDP for the full sample; while the median decline in debt from peak to trough, the contraction amplitude, is 10.7 percent of GDP. Consequently, the median slope of debt expansion (contraction) is 2.4 (1.8) percent of GDP. The majority of expansions (contractions) are described by moderate amplitudes and slopes, as positive differences between means and medians and high standard errors suggest. The lengthier expansion episodes with more sizeable amplitudes and slopes can be interpreted as an outcome of a "deficit bias" (see Debrun et al., 2009 for a survey), with persistence of fiscal consolidations being more difficult to achieve in financial recoveries amid common-pool issues and political pressures.

Across country groups, average debt expansions tend to be longer (8.1 years) and larger amplitude (25.0 percent of GDP) in advanced economies compared to emerging economies (6.3 years and 19.9 percent). The amplitudes of expansions tend to be higher in advanced economies given their ability to sustain higher levels of public debt. Similarly, average debt contractions tend to be longer (6.4 years) in advanced economies compared to emerging economies (5.9 years), despite smaller amplitude (14.2 versus 25.0 percent of GDP). These statistics reflect the ability of advanced economies to exert more persistent consolidation efforts amid better institutions and fiscal rules.

Figure 1 shows the frequency and amplitudes of debt expansions and contractions depending on their length. As expected, lengthier expansions and contractions have larger amplitudes. Shortest expansions and contractions are limited to 2 years, while longest expansions (contractions) last 26 (19) years.

\section{Determinants of Public Debt Dynamics around Expansion/Contraction Episodes}

To analyze determinants of public debt dynamics, we employ the simple stock-flow relation (Escolano, 2010): 


$$
d_{t}=\frac{\left(1+i_{t}\right)}{\left(1+g_{t}\right)\left(1+\pi_{t}\right)} d_{t-1}-p b_{t}+s f a_{t}
$$

The current level of public debt-to-GDP ratio $\left(d_{t}\right)$ depends on the following components: (i) the lagged debt-to-GDP ratio multiplied by the ratio of nominal effective interest rate $\left(i_{t}\right)$ and nominal GDP growth, with $g_{t}$ and $\pi_{t}$ denoting real GDP and GDP deflator growth rates, respectively; and (ii) the primary balance $\left(p b_{t}\right)$; and (iii) the stock-flow adjustment term (sfat) capturing valuation effects and "below-the-line" fiscal operations, including errors and omissions. The debt dynamics equation suggests that, given initial debt level (and assuming away the impact of stock-flow adjustments for simplicity), debt expansions are supported by high interest rates, and low real GDP growth, GDP deflator growth, and primary balance levels. The opposite relationship holds for debt contractions.

Table 4 shows descriptive statistics and Figures $2-3$ evolution of determinants of debt dynamics around debt expansion and contraction episodes, respectively. Debt expansions are preceded by debt contractions and start from a median level of debt-to-GDP ratio of 25 (34) percent in advanced (emerging) economies. As expected, debt expansions are supported by a rapid slowdown of real GDP growth rates and decline of the median primary balance from surplus to deficit. The increase in nominal interest rates is more pronounced in emerging economies, while decline in inflation in advanced economies. As a result, real interest rates rise in both groups of countries. There is wide variation across median levels of respective variables.

Similarly, debt contractions are preceded by debt expansions and start from a median level of debt-to-GDP ratio of 48 (51) percent in advanced (emerging) economies, even though the 10 percentile range is quite wide. Debt contractions are supported by a rapid improvement of real GDP growth rates and primary balances, as well as reduction in nominal interest rates. The increase in median inflation is more modest, but real interest rates nevertheless decline in both groups of countries. Again, there is wide variation across median levels of respective variables.

Figure 4 provides non-parametric analysis of the impact of financial cycles on debt cycles using the Kaplan-Meier survival functions. The expansion sample is split into episodes preceded by a peak in house prices (66 episodes), equity prices (76 episodes), and credit (75 episodes), and not preceded by peaks. Similarly, the contraction sample is split into episodes preceded by a trough in house prices (65 episodes), equity prices (64 episodes), and credit (66 episodes), and not preceded by troughs. There is evidence of asymmetric relationship between financial and debt cycles. For instance, about 75 (60) percent of debt expansions that were not (were) preceded by house price peaks end after 10 years, suggesting that house price busts lengthen debt expansions. Comparing the same indicators for debt contractions shows a much smaller difference ( 80 versus 75 percent), suggesting that the impact of house price cycles on debt expansions and contractions is asymmetric. Similar results hold also for equity price and credit cycles.

One drawback of the non-parametric analysis is that it does not allow conditioning on macroeconomic and other determinants of debt cycles. The parametric analysis conducted below addresses this issue. 


\section{DURATION ANALYSIS}

In this section, we employ a parametric duration model to examine determinants of public debt cycles, with a special focus on the impact of financial cycles. Duration models have been used widely to study expansion and contraction phases of business cycles (Claessens et al., 2009, 2012, and 2014), but no study analyzed a complete debt cycle and linked its dynamics to financial cycles.

\section{A. Baseline Specification}

Let the probability that the current spell of debt expansion (or contraction) $T$ is greater than some amount of time $t$. This probability is defined as the survivor function: $S(t)=\operatorname{Pr}(T \geq t)$. Defining the failure function as $F(t)=1-S(t)$ and its density as $f(t)=d F(t) / d t$, the hazard is given by:

$$
h(t)=\frac{f(t)}{S(t)}
$$

The hazard measures the likelihood at which spells of debt expansion (or contraction) terminate at $t$, given that they have lasted until $t$. One of the objectives of the duration analysis is to determine whether different phases of public debt cycles exhibit duration dependence $-a$ possibility that debt expansion (contraction) is more likely to end the longer it lasts. Another important objective is to assess the impact of conditioning factors, such as determinants of debt dynamics and other macro-financial variables, on the hazard rate. Following previous studies (e.g., Baldacci et al., 2012), we adopt the Weibull Parametric Duration Model that allows testing for duration dependence and analyzing the impact of conditioning factors:

$$
h(t, X)=p t^{p-1} \exp \left(X^{\prime} \beta\right)
$$

where $h($.$) is the hazard function measuring the probability that a period of debt expansion$ (contraction) will end at period $t, p$ is the Weibull parameter defining the extent of duration dependence. When $p=1$, the hazard rate is constant; while $p>(<) 1$ indicates positive (negative) duration dependence. We include initial values of determinants of debt dynamics mentioned above $(X)$ and country fixed-effects as controls in the baseline specification. We then examine the influence of financial cycles on the likelihood of exiting from expansion (contraction) phases of the cycle.

Table 5 shows estimation results for the baseline specification. Panel A shows regressions for debt expansions, and Panel B regressions for debt contractions. Column I reports results with only country fixed-effects. We find evidence of positive duration dependence for both phases of debt cycles with $p$ significantly greater than 1 - that is, debt expansions and contractions are more likely to end, the longer they have lasted. For instance, the level of parameter $p$ of 1.9 (2.2) for debt expansions (contractions) indicates that after 5 years the likelihood of exit from expansion (contraction) spell is 7 (14) times higher than after 1 year. While the finding for contraction episodes is consistent with previous duration studies on fiscal consolidations, the evidence for debt expansions is new. 
Column II shows estimations with determinants of debt dynamics included as controls. These include the initial level of debt ratio and average levels of real GDP growth, inflation, nominal interest rate, and primary balance over $[t-1, t+1]$ period around the start of debt expansions and contractions. ${ }^{5}$ Coefficient of the initial debt ratio is negative and significant in the contraction specification, suggesting that debt contractions tend to last longer if they start from a larger debt ratio. A 1 percentage points higher debt-to-GDP ratio decreases the hazard of ending consolidation by about 1.2 percent. This finding is in line with previous duration studies on fiscal consolidations (Von Hagen et al., 2002; Maroto and Mulas-Granados, 2008; Baldacci et al., 2012) and indicates that persistence of adjustment effort increases in the debt level. By contrast, the coefficient of the initial debt ratio is positive and significant in the expansion specification, suggesting that debt expansions tend to be short-lived if started from a higher level of debt. A 1 percentage points higher debt-to-GDP ratio increases the hazard of ending expansion by about 1.5 percent. This result is new and indicates debt sustainability/fiscal space concerns limiting the ability of countries to expand when initial debt level is already high. Coefficients of other determinants of debt dynamics are insignificant, with the exception of primary balance (negative sign) and inflation (positive sign) in the debt contraction specification. The latter results suggest that debt contraction started in periods of higher primary balance ratio and lower inflation tend to last longer. A 1 percentage points higher primary balance-to-GDP ratio (inflation) decreases (increases) the hazard of ending consolidation by about 12.2 (1.1) percent.

We next examine the impact of financial cycles on the duration of debt expansions and contractions. Following Claessens et al. (2009, 2012, and 2014), we include three dummy variables as additional explanatory variables. For debt expansion specifications, the dummies take the value of one if expansion coincides with overheated credit market and asset (house and equity) prices in periods [t-1, t+1], and zero otherwise, with overheating measured as peaks of respective detrended variables. Intuitively, debt expansions preceded by financial booms are expected to last longer as financial disruptions following the booms tend to have a lasting impact on economic recovery (negative coefficient). For debt contraction specifications, the dummies take the value of one if contractions coincide with depressed credit market or asset (house and equity) prices in periods $[t-1, t+1]$, and zero otherwise, with depression captured as troughs of respective detrended variables. If the relationship between financial and debt cycles is symmetric, then recovering financial markets should help prolonging debt contractions through positive effects on the economic recovery (positive coefficient).

Columns III, IV, and V show that debt expansions preceded by overheating in credit and financial markets tend to last longer than other expansions, even after taking into account individual country circumstances (through country fixed effects). Expansions preceded by house price, equity price, and credit booms have 63, 35, and 52 percent lower hazard of ending, respectively, relative to expansions not preceded by financial booms. The longer period of debt expansions is in line with evidence on longer economic recovery following financial booms (IMF, 2015). Inclusion of all three financial dummies simultaneously in Column VI does not affect the signs of coefficients, but only house price coefficients stays significant due to collinearity driven by high

\footnotetext{
${ }^{5}$ We also use contemporary changes in real GDP growth, inflation, nominal interest rate, and primary balance variables over the respective phase of the cycle, but results remain qualitatively unchanged.
} 
synchronization of credit and asset price markets (Liu et al., 2015). By contrast, financial cycles have no significant impact on debt contractions. This suggests that the relationship between different phases of financial and debt cycles is asymmetric, which could be driven by procyclical fiscal policies that offset automatic stabilizers in periods of financial recovery. It is consistent with regime-switching VAR findings of Afonso et al. (2011) and Budina et al. (2015) regarding asymmetric reaction of debt dynamics to positive and negative financial shocks.

Columns VII-X report results for regressions with both debt determinants and financial cycle variables included as determinants of debt cycles. The asymmetric relationship between debt and financial cycles continues to hold.

\section{B. Robustness Checks}

We examine the robustness of our main result on the asymmetric relationship between debt and financial cycles by controlling for other variables.

\section{Global factors}

Table 6 shows estimation results using global factors as additional controls. We include world real GDP growth and percentage change in real oil prices over $[t-1, t+1]$ period around the start of debt expansions and contractions as global factors. Debt expansions are found to last longer when starting in periods of high oil price growth, while debt contractions tend to be more shortlived when accompanied by high world growth. This result is consistent with the findings of Von Hagen and Strauch (2001) suggesting that fiscal consolidation is more likely to be successful under bleak international economic circumstances. The asymmetric relationship between debt and financial cycles remains unaffected by the inclusion of global factors.

\section{Openness}

Table 7 shows estimation results using openness variables as additional controls. We include a dummy variable that takes value of 1 for Eurozone countries after introduction of a single currency. These countries cannot benefit from quick nominal exchange rate depreciation to facilitate fiscal adjustment (see discussion of Baldacci et al, 2012 by Michael Devereux). We also include trade openness and change in real exchange rate, to control for improvements in external competitiveness as important factors facilitating fiscal adjustment (Heylen and Everaert, 2000; Lambertini and Tavares, 2005; and Perotti, 2011). There is some evidence on longer lasting debt contractions for more open countries, while other coefficients are insignificant. The asymmetric relationship between debt and financial cycles remains unaffected by the inclusion of these openness controls.

\section{Political stability}

Table 8 shows estimation results using a political factor as an additional control. We include an average index of political stability (Polity IV) over $[t-1, t+1]$ period around the start of debt expansions and contractions, to control for political drivers of fiscal adjustment (Maroto and Mulas-Granados, 2008). We find some evidence that persistence of debt contraction is stronger 
in countries with more stable political environment. The asymmetric relationship between debt and financial cycles remains unaffected by the inclusion of this political variable.

\section{Banking crises}

Table 9 shows estimation results using the cost of banking crises as an additional control. ${ }^{6}$ The cost of banking crises measures output loss in percent of GDP due to a banking crisis that took place over $[t-1, t+1]$ period around the start of debt expansions and contractions. There is some evidence that debt expansions preceded by banking crises are more short-lived the higher is the output loss, as countries hasten fiscal adjustment to offset fiscal costs associated with public debt buildup following the crises and as economies tend to recover faster when preceded by larger slumps. The significant association between the cost of banking crises and debt expansions is in line with results of previous studies (e.g., Reinhart and Rogoff, 2009; IMF, 2015). There is also some evidence that duration of debt contractions is shorter if preceded by banking crises with large output losses, as rescue of banks by the government makes it difficult to sustain debt contractions. The asymmetric relationship between debt and financial cycles remains unaffected by the inclusion of a banking crisis dummy.

\section{Amplitude of financial cycles}

Table 10 shows estimation results using subsamples of smaller deviations of financial variables from their fundamental value - not greater than respective average amplitudes during peaks (troughs). This reduces the sample by about 30-40 percent. The purpose of this exercise is to check whether the main results are driven by debt expansions (contractions) that were preceded by extremely large deviations of financial variables above (below) their fundamental values during peaks (troughs). As shown in the table, the main results remain unchanged, suggesting that the asymmetric association between financial and debt cycles holds even for financial cycles with relatively smaller amplitudes.

\section{CONCLUSIONS}

This paper employs a duration model to study determinants of public debt cycles in a sample of 57 advanced and emerging economies over the period 1960-2014, with a particular focus on the impact of financial cycles. It builds on the existing literature analyzing association between financial and business cycles (Claessens et al., 2009, 2012, and 2014) and extends it for the case of public debt cycles. Unlike previous studies on the duration of public debt cycles that focused on the contraction phase (e.g., Baldacci et al., 2012), the paper analyzes both contraction and expansion phases.

The analysis suggests that there is an asymmetric relationship between financial and public debt cycles. Debt expansions preceded by overheating in credit and financial markets tend to last longer than other expansions. This finding is in line with the results from the business cycles literature, showing that overheating in credit and financial markets leads to more pronounced

\footnotetext{
${ }^{6}$ IMF (2015) provides a comprehensive discussion of transmission channels from banking crises to sovereign debt buildups.
} 
periods of economic contraction (IMF, 2015). By contrast, financial cycles have no significant impact on debt contractions, suggesting that the relationship between different phases of financial and debt cycles is asymmetric. The asymmetric association between financial and public debt cycles supports the "deficit bias" hypothesis, according to which governments expand deficits to cushion recessions ("bad times") but do not rebuild fiscal buffers fully during recoveries ("good times"). It is consistent with regime-switching VAR findings of Afonso et al. (2011) and Budina et al. (2015) regarding asymmetric reaction of debt dynamics to positive and negative financial shocks. The novelty of our result is that it provides first evidence of "deficit bias" in relation to financial cycles within a duration framework. This result is robust to the inclusion of global factors, openness, political stability, and debt crisis indicators as additional controls.

We also find strong evidence of duration dependence for both phases of the debt cycle. In line with the consolidation fatigue hypothesis and results of previous studies, we find that debt contractions are more likely to end the longer they have lasted. The result on the duration dependence of debt expansions is new and provides support to the debt sustainability hypothesis, with countries finding it difficult to increase debt further conditional on a lengthy spell of ongoing expansion.

Among determinants of debt dynamics, the most significant factor is the initial level of debt. The spell of contraction is lengthier if started from a high initial level of debt (persistence of adjustment effort hypothesis), while the spell of expansion is shorter if started from a high initial level of debt (fiscal sustainability hypothesis). Other determinants of debt dynamics, including initial levels of real GDP growth, inflation, nominal interest rates, and primary balances are insignificant, with the exception of the primary balance that extends the period of contraction.

All in all, the results suggest that financial disruptions prolong the duration of debt expansions, but periods of financial recoveries are not used wisely to rebuild fiscal buffers and reduce debt to lower levels. These results have important policy implications. First, reforms aimed at strengthening fiscal institutions and reducing "deficit bias" are needed to prevent debt buildup over the financial cycle. One example is property taxation, where legislation typically allows tax rates to change within a certain range and governments tend to use this opportunity to reduce property taxes in a procyclical fashion during housing recoveries (Lutz, 2008). These reforms could be accompanied by effective macroprudential policies (such as caps on debt-to-income and loan-to-value, dynamic provisioning requirements) aimed at reducing systemic financial risks and associated contingent liabilities. Second, reforms aimed at reducing tax incentives that encourage debt over equity financing need to continue to reduce tax-driven excessive leverage (De Mooij, 2012). For instance, the tax deductibility of interest payments on mortgages could be limited to mitigate the bias towards debt financing of property investments. Finally, financial cycles and related contingent liabilities need to be taken into account when evaluating government's fiscal space. This requires putting in place an institutional framework that strengthens the ability of fiscal authorities to identify and monitor risks from the financial sector and generate adequate early warnings. 


\section{REFERENCES}

Afonso, A., J. Baxa, and M. Slavik, 2011, "Fiscal Developments and Financial Stress: A Threshold VAR Analysis," ECB Working Paper No. 1319 (Frankfurt: European Central Bank).

Baldacci, E., S. Gupta, and C. Mulas-Granados, 2010, "Restoring Debt Sustainability after Crises: Implications for the Fiscal Mix," IMF Working Paper No. 10/232 (Washington: International Monetary Fund).

Baldacci, E., S. Gupta, and C. Mulas-Granados, 2012, "Reassessing the Fiscal Mix for Successful Debt Reduction," Economic Policy, 27(71): pp. 365-406.

Benetrix, A. and P. Lane, 2013, "Fiscal Cyclicality and EMU," Journal of International Money and Finance, 34: pp. 164-76.

Bernanke, B., M. Gertler, and S. Gilchrist, 1999, "The Financial Accelerator in A Quantitative Business Cycle Framework," in: Taylor, J., Woodford, M. (eds.), Handbook of Macroeconomics, Vol. 1 (Chapter 21): pp. 1341-93.

Borio, C., 2014, "The Financial Cycle and Macroeconomics: What Have We Learnt?" Journal of Banking and Finance, 45: pp. 182-98.

Bry, G. and C. Boschan, 1971, "Cyclical Analysis of Economic Time Series: Selected Procedures and Computer Programs", NBER Technical Working Paper No. 20 (Cambridge, Massachusetts: National Bureau of Economic Research).

Budina, N., B. Gracia, X. Hu, and S. Saksonovs, 2015, "Recognizing the Bias: Financial Cycles and Fiscal Policy," IMF Working Paper (forthcoming) (Washington: International Monetary Fund).

Claessens, S., A. Kose, and M. Terrones, 2009, "What Happens During Recessions, Crunches, and Busts?" Economic Policy, 60: pp. 653-700.

Claessens, S., A. Kose, and M. Terrones, 2012, "How Do Business and Financial Cycles Interact?" Journal of International Economics, 87: pp. 178-90.

Claessens, S., A. Kose, and M. Terrones, 2014, "The Global Financial Crisis: How Similar? How Different? How Costly?" in: Claessens, S., A. Kose, L. Laeven, and F. Valencia (eds.), Financial Crises: Causes, Consequences, and Policy Responses, (Washington: International Monetary Fund).

De Mooij, R., 2012, "Tax Biases to Debt Finance: Assessing the Problem, Finding Solutions," Fiscal Studies 33, 489-512.

Debrun, X., D. Hauner, and M. Kumar, 2009, "Independent Fiscal Agencies," Journal of Economic Surveys, 23: pp. 44-81. 
Drehmann, M., C. Borio, and K. Tsatsaronis, 2012, "Characterizing the Financial Cycle: Don't Lose Sight of the Medium Term!" BIS Working Paper No. 380 (Basel: Bank for International Settlements).

Escolano, J., 2010, "A Practical Guide to Public Debt Dynamics, Fiscal Sustainability, and Cyclical Adjustment of Budgetary Aggregates," IMF Technical Notes and Manuals No. 10/02 (Washington: International Monetary Fund).

Gupta, S., E. Baldacci, B. Clements, and E. Tiongson, 2005, "What Sustains Fiscal Consolidations in Emerging Market Countries?" International Journal of Finance and Economics, 10: pp. 307-21.

Harding, D. and A. Pagan, 2002, "Dissecting the Cycle: A Methodological Investigation," Journal of Monetary Economics 49: pp. 365-81.

Helbling, T., H. Raju, A. Kose, and C. Otrok, 2011, "Do Credit Shocks Matter? A Global Perspective," European Economic Review, 55: pp. 340-53.

Heylen, F. and G. Everaert, 2000, "Success and Failure of Fiscal Consolidation in the OECD: A Multivariate Analysis," Public Choice, 105: pp. 103-24.

IMF, 2015, "From Banking to Sovereign Stress: Implications for Sovereign Debt", IMF Policy Paper (available at: https://www.imf.org/external/np/pp/eng/2014/122214.pdf).

Jorda, O., M. Schularick, and A. Taylor, 2015, "Sovereigns Versus Banks: Credit, Crises, and Consequences," Journal of the European Economic Association (forthcoming).

Kiyotaki, N. and J. Moore, 1997, "Credit Cycles," Journal of Political Economy, 105: pp. 211-48.

Lambertini, L. and J. Tavares, 2005, "Exchange Rates and Fiscal Adjustments: Evidence from the OECD and Implications for the EMU," Contributions to Macroeconomics, 5(1): pp. 1-28.

Laeven, L. and F. Valencia, 2012, "Systemic Banking Crises Database: An Update," IMF Working Paper No. 12/163 (Washington: International Monetary Fund).

Liu, E., T. Mattina, and T. Poghosyan, 2015, "Correcting "Beyond the Cycle:" Accounting for Asset Prices in Structural Fiscal Balances," IMF Working Paper No. 15/109 (Washington: International Monetary Fund).

Lutz, B., 2008, "The Connection Between House Price Appreciation and Property Tax Revenues", Finance and Economics Discussion Series No. 2008-48 (Washington: Federal Reserve Board).

Maroto, R. and C. Mulas-Granados, 2008, "What Makes Fiscal Consolidations Last? A Survival Analysis of Budget Cuts in Europe (1960-2004)," Public Choice, 134(3-4): pp. 147-61. 
Marshall, M. and K. Jaggers, 2002, "Polity IV Data Set," Center for International Development and Conflict Management, University of Maryland.

Mauro, P., R. Romeu, A. Binder, and A. Zaman, 2013, "A Modern History of Fiscal Prudence and Profligacy," IMF Working Paper No. 13/5 (Washington: International Monetary Fund).

Perotti, R., 2011, "The "Austerity Myth:" Gain Without Pain?" NBER Working Paper No. 17571 (Cambridge, Massachusetts: National Bureau of Economic Research).

Reinhart, C. and K. Rogoff, 2009, "This Time is Different: Eight Centuries of Financial Folly," (Princeton: Princeton University Press).

Von Hagen, J. and R. Strauch, 2001, "Fiscal Consolidations: Quality, Economic Conditions, and Success," Public Choice, 109: pp. 327-46.

Von Hagen, J., A. Hughes Hallett., and R. Strauch, 2002, "Budgetary Consolidation in Europe: Quality, Economic Conditions, and Persistence," Journal of the Japanese and International Economies, 16: pp. 512-35. 
Table 1. List of Countries

\begin{tabular}{|c|c|}
\hline Advanced economies & Emerging economies \\
\hline Australia & Argentina \\
\hline Austria & Bolivia \\
\hline Belgium & Brazil \\
\hline Canada & Bulgaria \\
\hline Denmark & Chile \\
\hline Finland & China \\
\hline France & Colombia \\
\hline Germany & Costa Rica \\
\hline Greece & Dominican Republic \\
\hline Hong Kong & Ghana \\
\hline Hong Kong SAR & Honduras \\
\hline Ireland & Hungary \\
\hline Israel & Iceland \\
\hline Italy & India \\
\hline Japan & Indonesia \\
\hline Korea & Iran \\
\hline Netherlands & Mexico \\
\hline New Zealand & Nicaragua \\
\hline Norway & Pakistan \\
\hline Portugal & Panama \\
\hline Romania & Paraguay \\
\hline South Korea & Peru \\
\hline Spain & Philippines \\
\hline Sweden & Poland \\
\hline Switzerland & Russia \\
\hline United Kingdom & South Africa \\
\hline \multirow[t]{4}{*}{ United States } & Thailand \\
\hline & Turkey \\
\hline & Uruguay \\
\hline & Venezuela \\
\hline
\end{tabular}

Note: 57 countries in total (30 emerging economies and 27 advanced countries). Source: Mauro et al. (2013). 
Table 2. Variables and Data Sources

\begin{tabular}{|c|c|c|c|}
\hline Variable & Definition & Frequency & Source \\
\hline \multicolumn{4}{|c|}{$\underline{\text { Sovereign debt cycles }}$} \\
\hline \multicolumn{3}{|c|}{ Financial cycles } & Mauro et al. (2013) \\
\hline House prices & Nominal house prices, deflated using CPI & Quarterly & Liu et al. (2015) \\
\hline Equity prices & Share price index, deflated using CPI & Quarterly & Liu et al. (2015) \\
\hline \multicolumn{4}{|c|}{ Determinants of sovereign cycles } \\
\hline \multicolumn{4}{|l|}{ Drivers of debt dynamics } \\
\hline Primary balance & Government primary balance, share of GDP & Annual & Mauro et al. (2013) \\
\hline Growth & Real GDP, percentage change & Annual & Mauro et al. (2013) \\
\hline Inflation & GDP deflator, percentage change & Annual & Mauro et al. (2013) \\
\hline Interest rate & $\begin{array}{l}\text { Government interest spending, divided over lagged } \\
\text { gross public debt }\end{array}$ & Annual & Mauro et al. (2013) \\
\hline \multicolumn{4}{|l|}{ Global factors } \\
\hline World growth & World real GDP, percentage change & Annual & WEO \\
\hline Oil price growth & $\begin{array}{l}\text { Oil prices in USD divided over US GDP deflator, } \\
\text { percentage change }\end{array}$ & Annual & WEO \\
\hline \multicolumn{4}{|c|}{ r } \\
\hline Trade openness & $\begin{array}{l}\text { Total imports and exports of goods and services, share } \\
\text { of GDP }\end{array}$ & Annual & WEO \\
\hline Real effective exchange rate & $\begin{array}{l}\text { Real effective exchange rate index }(2005=100) \\
\text { percentage change }\end{array}$ & Annual & WEO \\
\hline \multicolumn{4}{|l|}{ Political factors } \\
\hline Political stability & Polity IV index & Annual & $\begin{array}{l}\text { Marshall and } \\
\text { Jaggers (2002) }\end{array}$ \\
\hline \multicolumn{4}{|l|}{ Banking crises } \\
\hline Banking crises & Output loss due to a banking crisis (percent of GDP) & Annual & Laeven and Valencia (2012) \\
\hline
\end{tabular}


Table 3. Characteristics of Debt Expansions and Contractions

\begin{tabular}{|c|c|c|c|c|c|c|c|c|c|c|}
\hline & \multirow{2}{*}{$\begin{array}{l}\text { Number } \\
\text { of events }\end{array}$} & \multicolumn{3}{|c|}{ Duration (years) } & \multicolumn{3}{|c|}{ Amplitude (\% of GDP) } & \multicolumn{3}{|c|}{ Slope (\% of GDP) } \\
\hline & & Mean & Median & St. Dev. & Mean & Median & St. Dev. & Mean & Median & St. Dev. \\
\hline \multicolumn{11}{|l|}{ A. Debt expansions } \\
\hline Emerging economies & 120 & 6.3 & 6.0 & 3.7 & 19.9 & 13.6 & 21.2 & 3.3 & 2.2 & 3.6 \\
\hline Advanced economies & 89 & 8.1 & 6.0 & 5.7 & 25.0 & 16.0 & 25.9 & 2.8 & 2.4 & 2.4 \\
\hline Total sample & 209 & 7.0 & 6.0 & 4.7 & 22.1 & 14.5 & 23.4 & 3.1 & 2.4 & 3.1 \\
\hline \multicolumn{11}{|l|}{ B. Debt contractions } \\
\hline Emerging economies & 118 & 5.9 & 5.0 & 3.5 & 25.0 & 12.9 & 38.2 & 3.6 & 2.4 & 3.9 \\
\hline Advanced economies & 89 & 6.4 & 5.0 & 4.3 & 14.2 & 9.7 & 19.1 & 2.1 & 1.4 & 4.3 \\
\hline Total sample & 207 & 6.1 & 5.0 & 3.8 & 20.4 & 10.7 & 31.8 & 3.0 & 1.8 & 4.2 \\
\hline
\end{tabular}

Source: Own calculations, using the methodology of Harding and Pagan (2002). 
Table 4. Descriptive Statistics of Determinants of Public Debt Dynamics

\begin{tabular}{|c|c|c|c|c|c|c|c|c|c|c|c|c|c|c|c|c|}
\hline & \multirow[t]{2}{*}{$\begin{array}{l}\text { Number } \\
\text { of events }\end{array}$} & \multicolumn{3}{|c|}{$\begin{array}{c}\text { Initial level of } \\
\text { debt (t-1) }\end{array}$} & \multicolumn{3}{|c|}{$\begin{array}{l}\text { Current level of } \\
\text { primary balance }(t)\end{array}$} & \multicolumn{3}{|c|}{$\begin{array}{l}\text { Current level of } \\
\text { real GDP growth }(t)\end{array}$} & \multicolumn{3}{|c|}{$\begin{array}{l}\text { Current level of } \\
\text { CPI inflation ( } t)\end{array}$} & \multicolumn{3}{|c|}{$\begin{array}{l}\text { Current level of } \\
\text { real effective rate }(t)\end{array}$} \\
\hline & & Mean & Median & St. Dev. & Mean & Median & St. Dev. & Mean & Median & St. Dev. & Mean & Median & St. Dev. & Mean & Median & St. Dev. \\
\hline \multicolumn{17}{|l|}{ A. Debt expansions } \\
\hline Emerging economies & 120 & 29.5 & 25.5 & 25.3 & 0.4 & 0.2 & 2.7 & 5.2 & 5.3 & 4.9 & 17.1 & 10.9 & 35.9 & -5.6 & -4.9 & 12.2 \\
\hline Advanced economies & 89 & 37.5 & 33.9 & 29.5 & 1.7 & 1.3 & 2.8 & 3.4 & 3.3 & 3.2 & 7.5 & 5.0 & 9.9 & 0.2 & 1.3 & 5.5 \\
\hline Total sample & 209 & 32.9 & 27.5 & 27.4 & 1.0 & 0.6 & 2.8 & 4.4 & 4.3 & 4.3 & 12.8 & 7.8 & 27.9 & -2.8 & -0.4 & 10.0 \\
\hline \multicolumn{17}{|l|}{ B. Debt contractions } \\
\hline Emerging economies & 118 & 60.9 & 48.3 & 48.6 & -0.5 & -0.5 & 3.0 & 3.2 & 3.7 & 5.2 & 31.4 & 10.6 & 67.8 & -10.0 & -4.7 & 17.5 \\
\hline Advanced economies & 89 & 57.1 & 51.3 & 41.2 & 0.9 & 0.6 & 3.4 & 3.6 & 3.5 & 3.0 & 6.0 & 2.9 & 17.9 & 1.7 & 2.9 & 8.9 \\
\hline Total sample & 207 & 59.3 & 49.9 & 45.5 & 0.1 & 0.1 & 3.2 & 3.3 & 3.6 & 4.4 & 20.0 & 5.2 & 53.1 & -4.6 & 0.6 & 15.3 \\
\hline
\end{tabular}

Source: Own calculations, using the methodology of Harding and Pagan (2002). t refers to the year when debt expansions (contractions) have started. 
Table 5. Baseline Results

\begin{tabular}{|c|c|c|c|c|c|c|c|c|c|c|}
\hline & (I) & (II) & (III) & (IV) & (V) & (VI) & (VII) & (VIII) & $(\mathrm{IX})$ & $(\mathrm{X})$ \\
\hline \multirow[t]{2}{*}{ Initial debt-to-GDP ratio (t) } & & $0.011^{* *}$ & & & & & 0.008 & $0.013^{* *}$ & $0.013^{* *}$ & $0.012^{* *}$ \\
\hline & & {$[0.005]$} & & & & & [0.005] & {$[0.005]$} & {$[0.005]$} & {$[0.006]$} \\
\hline \multirow[t]{2}{*}{ Primary balance (average over $[\mathrm{t}-1 ; \mathrm{t}+1]$ ) } & & -0.06 & & & & & -0.021 & -0.031 & -0.062 & -0.002 \\
\hline & & {$[0.055]$} & & & & & [0.057] & {$[0.057]$} & {$[0.054]$} & {$[0.059]$} \\
\hline \multirow[t]{2}{*}{ Real GDP growth (average over $[t-1 ; t+1]$ ) } & & -0.033 & & & & & -0.055 & -0.029 & -0.031 & -0.048 \\
\hline & & [0.051] & & & & & [0.053] & {$[0.052]$} & {$[0.051]$} & {$[0.054]$} \\
\hline \multirow[t]{2}{*}{ Nominal interest rate (average over $[\mathrm{t}-1 ; \mathrm{t}+1]$ ) } & & 0.002 & & & & & -0.005 & 0.003 & 0.01 & 0.002 \\
\hline & & [0.018] & & & & & [0.018] & {$[0.018]$} & [0.019] & {$[0.019]$} \\
\hline \multirow[t]{2}{*}{ CPI inflation (average over [t-1;t+1]) } & & 0.008 & & & & & 0.008 & 0.008 & 0.003 & 0.005 \\
\hline & & [0.009] & & & & & [0.009] & {$[0.009]$} & [0.009] & {$[0.009]$} \\
\hline \multirow[t]{2}{*}{ Expansion coincided with house price bust } & & & $-1.006^{* * *}$ & & & $-0.849^{* * * *}$ & $-0.974^{* * *}$ & & & $-0.854^{* * *}$ \\
\hline & & & [0.293] & & & {$[0.306]$} & [0.319] & & & {$[0.328]$} \\
\hline \multirow[t]{2}{*}{ Expansion coincided with equity price bust } & & & & $-0.424^{*}$ & & -0.209 & & $-0.557^{*}$ & & -0.482 \\
\hline & & & & {$[0.255]$} & & {$[0.269]$} & & {$[0.285]$} & & {$[0.298]$} \\
\hline \multirow[t]{2}{*}{ Expansion coincided with credit bust } & & & & & $-0.725 * *$ & -0.439 & & & $-0.678^{*}$ & -0.387 \\
\hline & & & & & [0.295] & [0.319] & & & {$[0.361]$} & {$[0.382]$} \\
\hline \multirow[t]{2}{*}{ Constant } & $-5.200 * * *$ & $-4.764^{* * *}$ & $-5.500 * * *$ & $-4.095 * * *$ & $-5.681 * * *$ & $-5.224 * * *$ & $-3.968^{* *}$ & $-5.163^{* * *}$ & $-5.077^{* * *}$ & $-4.678^{* * *}$ \\
\hline & [1.041] & [1.574] & [1.089] & {$[0.788]$} & [1.094] & [1.112] & [1.599] & [1.582] & {$[1.587]$} & [1.632] \\
\hline Observations & 208 & 181 & 208 & 208 & 208 & 208 & 181 & 181 & 181 & 181 \\
\hline Weibul parameter $(\mathrm{p})$ & 1.951 & 2.109 & 2.014 & 1.949 & 1.981 & 2.021 & 2.169 & 2.12 & 2.129 & 2.186 \\
\hline \multicolumn{11}{|l|}{ B. Debt contractions } \\
\hline & (I) & (III) & (III) & (IV) & (V) & (VI) & (VII) & (VIII) & $(\mathrm{IX})$ & $(\mathrm{X})$ \\
\hline \multirow[t]{2}{*}{ Initial debt-to-GDP ratio (t) } & & $-0.015^{* * *}$ & & & & & $-0.016^{* * *}$ & $-0.014^{* * *}$ & $-0.015^{* * *}$ & $-0.015^{* * *}$ \\
\hline & & [0.004] & & & & & [0.005] & {$[0.005]$} & {$[0.004]$} & [0.005] \\
\hline \multirow[t]{2}{*}{ Primary balance (average over $[\mathrm{t}-1 ; \mathrm{t}+1]$ ) } & & $-0.130^{* *}$ & & & & & $-0.129 * *$ & $-0.136 * *$ & $-0.128^{* *}$ & $-0.134 * *$ \\
\hline & & {$[0.058]$} & & & & & {$[0.058]$} & {$[0.059]$} & {$[0.058]$} & {$[0.058]$} \\
\hline \multirow[t]{2}{*}{ Real GDP growth (average over $[\mathrm{t}-1 ; \mathrm{t}+1]$ ) } & & -0.037 & & & & & -0.037 & -0.045 & -0.034 & -0.047 \\
\hline & & [0.043] & & & & & {$[0.043]$} & {$[0.044]$} & {$[0.044]$} & {$[0.045]$} \\
\hline \multirow[t]{2}{*}{ Nominal interest rate (average over $[t-1 ; t+1]$ ) } & & 0.014 & & & & & 0.014 & 0.022 & 0.012 & 0.023 \\
\hline & & [0.027] & & & & & {$[0.028]$} & {$[0.028]$} & {$[0.028]$} & {$[0.028]$} \\
\hline \multirow[t]{2}{*}{ CPI inflation (average over $[t-1 ; t+1]$ ) } & & $0.012^{*}$ & & & & & $0.012^{*}$ & 0.01 & $0.012 *$ & 0.011 \\
\hline & & {$[0.007]$} & & & & & {$[0.007]$} & {$[0.007]$} & {$[0.007]$} & {$[0.008]$} \\
\hline \multirow[t]{2}{*}{ Contraction coincided with house price boom } & & & 0.038 & & & 0.242 & 0.091 & & & 0.220 \\
\hline & & & {$[0.223]$} & & & [0.263] & [0.259] & & & [0.305] \\
\hline \multirow[t]{2}{*}{ Contraction coincided with equity price boom } & & & & -0.307 & & -0.424 & & -0.283 & & -0.406 \\
\hline & & & & [0.229] & & [0.266] & & [0.284] & & [0.314] \\
\hline \multirow[t]{2}{*}{ Contraction coincided with credit boom } & & & & & -0.071 & -0.004 & & & 0.128 & 0.119 \\
\hline & & & & & [0.263] & [0.290] & & & [0.319] & {$[0.345]$} \\
\hline \multirow[t]{2}{*}{ Constant } & $-3.559 * * *$ & -12.671 & $-3.560^{* * *}$ & -17.067 & $-3.561^{* * *}$ & $-3.579 * * *$ & -13.006 & $-5.178^{* * *}$ & -13.453 & $-4.022^{* * *}$ \\
\hline & [1.021] & [72.763] & [1.022] & [396.002] & [1.022] & [1.022] & [86.613] & [1.367] & [106.654] & [1.128] \\
\hline Observations & 205 & 171 & 205 & 205 & 205 & 205 & 171 & 171 & 171 & 171 \\
\hline Weibul parameter $(\mathrm{p})$ & 2.212 & 2.46 & 2.212 & 2.217 & 2.213 & 2.224 & 2.463 & 2.459 & 2.461 & 2.467 \\
\hline
\end{tabular}

Note: Duration regressions are performed using the Weibull model. All regressions include country fixed-effects. Robust standard errors are in brackets. ${ }^{*}{ }^{* *}$, and ${ }^{* * *}$ denote significance at the 10 percent, 5 percent, and 1 percent levels, respectively. The dependent variables are: (i) duration of debt expansion in panel A; and (ii) duration of debt contraction in panel B. Dummies for debt expansions coincided with financial (house price, equity price, and credit) busts take on a value of 1 if financial variables reached peak during $[t-1 ; t+1]$. Dummies for debt contractions coincided with financial (house price, equity price, and credit) booms take on a value of 1 if financial variables reached trough during $[t-1 ; t+1]$. $t$ refers to the year when debt expansions (contractions) have started. The Weibull parameter is significantly different from 1 in all specifications at 1 percent confidence level. 
Table 6. Robustness to Global Factors

\begin{tabular}{|c|c|c|c|c|c|c|c|c|c|c|}
\hline & $(\mathrm{I})$ & (II) & (III) & (IV) & (V) & $(\mathrm{VI})$ & (VII) & (VIII) & $(\mathrm{IX})$ & $(\mathrm{X})$ \\
\hline \multirow[t]{2}{*}{ World GDP growth (average over [t-1;t+1]) } & -0.059 & 0.126 & -0.109 & -0.117 & -0.098 & $-0.164^{*}$ & 0.071 & 0.065 & 0.099 & 0.006 \\
\hline & {$[0.080]$} & [0.105] & {$[0.081]$} & {$[0.083]$} & {$[0.080]$} & {$[0.084]$} & {$[0.110]$} & {$[0.110]$} & {$[0.107]$} & {$[0.116]$} \\
\hline \multirow[t]{2}{*}{ Real oil price growth (average over $[t-1 ; t+1]$ ) } & $-0.033 * * *$ & $-0.030 * * *$ & $-0.030 * * *$ & $-0.034 * * *$ & $-0.033 * * *$ & $-0.031 * * *$ & $-0.027 * * *$ & $-0.032 * * *$ & $-0.030^{* * *}$ & $-0.029 * * *$ \\
\hline & {$[0.007]$} & [0.008] & [0.007] & {$[0.007]$} & {$[0.007]$} & [0.007] & [0.008] & [0.008] & {$[0.008]$} & [0.008] \\
\hline \multirow[t]{2}{*}{ Initial debt-to-GDP ratio $(\mathrm{t})$} & & $0.009 *$ & & & & & 0.007 & $0.011^{* *}$ & $0.011^{* *}$ & $0.011^{*}$ \\
\hline & & [0.005] & & & & & [0.005] & [0.006] & {$[0.005]$} & [0.006] \\
\hline \multirow[t]{2}{*}{ Primary balance (average over $[t-1 ; t+1]$ ) } & & -0.066 & & & & & -0.036 & -0.022 & -0.063 & -0.002 \\
\hline & & [0.055] & & & & & [0.057] & [0.059] & [0.054] & [0.061] \\
\hline \multirow[t]{2}{*}{ Real GDP growth (average over [t-1;t+1]) } & & -0.046 & & & & & -0.055 & -0.037 & -0.044 & -0.042 \\
\hline & & [0.051] & & & & & [0.052] & [0.051] & [0.051] & [0.053] \\
\hline \multirow[t]{2}{*}{ Nominal interest rate (average over $[\mathrm{t}-1 ; \mathrm{t}+1]$ ) } & & -0.017 & & & & & -0.019 & -0.017 & -0.009 & -0.013 \\
\hline & & {$[0.018]$} & & & & & {$[0.018]$} & [0.018] & [0.019] & [0.019] \\
\hline \multirow[t]{2}{*}{ CPI inflation (average over $[t-1 ; t+1]$ ) } & & $0.018^{* *}$ & & & & & $0.016^{*}$ & $0.018^{*}$ & 0.013 & 0.012 \\
\hline & & {$[0.009]$} & & & & & {$[0.009]$} & [0.009] & {$[0.010]$} & [0.010] \\
\hline \multirow[t]{2}{*}{ Expansion coincided with house price bust } & & & $-0.833^{* * *}$ & & & $-0.605^{*}$ & $-0.651^{*}$ & & & -0.526 \\
\hline & & & [0.312] & & & [0.328] & [0.339] & & & [0.350] \\
\hline \multirow[t]{2}{*}{ Expansion coincided with equity price bust } & & & & $-0.632 * *$ & & -0.424 & & $-0.607 * *$ & & $-0.559 *$ \\
\hline & & & & [0.265] & & [0.283] & & [0.304] & & {$[0.316]$} \\
\hline \multirow[t]{2}{*}{ Expansion coincided with credit bust } & & & & & $-0.745 * * *$ & -0.503 & & & $-0.634^{*}$ & -0.459 \\
\hline & & & & & [0.287] & {$[0.306]$} & & & [0.348] & [0.363] \\
\hline \multirow[t]{2}{*}{ Constant } & $-6.619 * * *$ & $-4.535^{* * *}$ & $-5.580 * * *$ & -15.217 & -15.966 & $-5.075^{* * *}$ & $-3.869 * *$ & $-4.571 * * *$ & $-4.741 * * *$ & $-4.275^{* *}$ \\
\hline & [1.161] & [1.681] & [1.217] & [294.501] & [404.796] & [1.243] & [1.721] & [1.705] & {$[1.690]$} & [1.743] \\
\hline Observations & 203 & 181 & 203 & 203 & 203 & 203 & 181 & 181 & 181 & 181 \\
\hline Weibul parameter $(p)$ & 2.089 & 2.247 & 2.118 & 2.098 & 2.133 & 2.144 & 2.256 & 2.253 & 2.272 & 2.279 \\
\hline \multicolumn{11}{|l|}{ B. Debt contractions } \\
\hline & (I) & (II) & (III) & (IV) & (V) & $(\mathrm{VI})$ & (VII) & (VIII) & $(\mathrm{IX})$ & $(\mathrm{X})$ \\
\hline \multirow[t]{2}{*}{ World GDP growth (average over [t-1;t+1]) } & $0.381^{* * *}$ & $0.470^{* * *}$ & $0.457^{* * *}$ & $0.450^{* * *}$ & $0.420^{* * *}$ & $0.492^{* * *}$ & $0.535^{* * *}$ & $0.505^{* * *}$ & $0.497^{* * *}$ & $0.546^{* * *}$ \\
\hline & [0.104] & [0.148] & [0.113] & {$[0.125]$} & [0.112] & {$[0.131]$} & {$[0.156]$} & {$[0.163]$} & {$[0.150]$} & [0.168] \\
\hline \multirow[t]{2}{*}{ Real oil price growth (average over $[t-1 ; t+1]$ ) } & 0.001 & -0.003 & 0.001 & 0.001 & 0 & 0 & -0.003 & -0.003 & -0.004 & -0.004 \\
\hline & {$[0.008]$} & {$[0.009]$} & {$[0.008]$} & [0.008] & [0.009] & [0.009] & {$[0.009]$} & {$[0.009]$} & {$[0.009]$} & {$[0.009]$} \\
\hline \multirow[t]{2}{*}{ Initial debt-to-GDP ratio (t) } & & $-0.010 * *$ & & & & & $-0.010 * *$ & $-0.010 * *$ & $-0.010^{* *}$ & $-0.010 * *$ \\
\hline & & [0.005] & & & & & [0.005] & [0.005] & {$[0.005]$} & [0.005] \\
\hline \multirow[t]{2}{*}{ Primary balance (average over $[\mathrm{t}-1 ; \mathrm{t}+1]$ ) } & & $-0.156 * * *$ & & & & & $-0.155^{* * *}$ & $-0.154 * * *$ & $-0.153^{* * *}$ & $-0.152 * * *$ \\
\hline & & [0.059] & & & & & [0.059] & [0.059] & [0.058] & [0.058] \\
\hline \multirow[t]{2}{*}{ Real GDP growth (average over [t-1;t+1]) } & & -0.071 & & & & & $-0.078^{*}$ & -0.07 & -0.066 & -0.074 \\
\hline & & [0.044] & & & & & {$[0.044]$} & [0.044] & [0.044] & [0.045] \\
\hline \multirow[t]{2}{*}{ Nominal interest rate (average over $[t-1 ; t+1]$ ) } & & $0.051^{*}$ & & & & & $0.056^{*}$ & $0.050^{*}$ & $0.048^{*}$ & $0.053^{*}$ \\
\hline & & [0.028] & & & & & [0.029] & [0.029] & [0.029] & [0.029] \\
\hline CPI inflation (average over $[t-1 ; t+1]$ ) & & 0.011 & & & & & 0.011 & 0.011 & $0.012^{*}$ & 0.012 \\
\hline & & [0.007] & & & & & {$[0.007]$} & [0.007] & {$[0.007]$} & [0.007] \\
\hline Contraction coincided with house price boom & & & $0.443^{*}$ & & & 0.379 & 0.368 & & & 0.307 \\
\hline & & & [0.243] & & & [0.268] & [0.268] & & & [0.302] \\
\hline Contraction coincided with equity price boom & & & & 0.268 & & 0.103 & & 0.153 & & 0.018 \\
\hline & & & & {$[0.270]$} & & [0.290] & & [0.306] & & [0.325] \\
\hline Contraction coincided with credit boom & & & & & 0.282 & 0.130 & & & 0.336 & 0.213 \\
\hline & & & & & [0.281] & [0.295] & & & [0.323] & [0.339] \\
\hline Constant & $-7.216^{* * *}$ & -17.49 & $-7.477^{* * *}$ & -19.13 & $-7.346 * * *$ & $-6.477 * * *$ & $-7.375^{* * *}$ & -16.386 & -16.592 & -15.215 \\
\hline & [1.125] & [209.028] & [1.138] & [324.691] & [1.136] & [1.206] & [1.429] & [109.608] & [123.535] & [55.337] \\
\hline Observations & 195 & 171 & 195 & 195 & 195 & 195 & 171 & 171 & 171 & 171 \\
\hline Weibul parameter $(p)$ & 2.307 & 2.537 & 2.33 & 2.323 & 2.311 & 2.334 & 2.56 & 2.545 & 2.545 & 2.561 \\
\hline
\end{tabular}

Note: Duration regressions are performed using the Weibull model. All regressions include country fixed-effects. Robust standard errors are in brackets. ${ }^{*}{ }^{* *}$, and ${ }^{* * *}$ denote significance at the 10 percent, 5 percent, and 1 percent levels, respectively. The dependent variables are: (i) duration of debt expansion in panel A, and (ii) duration of debt contraction in panel B. Dummies for debt expansions coincided with financial (house price, equity price, and credit) busts take on a value of 1 if financial variables reached peak during $[t-1 ; t+1]$. Dummies for debt contractions coincided with financial (house price, equity price, and credit) booms take on a value of 1 if financial variables reached trough during $[t-1 ; t+1]$. t refers to the year when debt expansions (contractions) have started. The Weibull parameter is significantly different from 1 in all specifications at 1 percent confidence level. 
Table 7. Robustness to Openness Indicators

\begin{tabular}{|c|c|c|c|c|c|c|c|c|c|c|}
\hline & (I) & (II) & (III) & (IV) & (V) & $(\mathrm{VI})$ & (VII) & (VIII) & $(\mathrm{IX})$ & $(\mathrm{X})$ \\
\hline \multirow[t]{2}{*}{ Dummy for Eurozone countries } & -0.441 & -0.39 & 0.167 & -0.279 & -0.352 & 0.276 & 0.249 & -0.217 & -0.245 & 0.383 \\
\hline & {$[0.607]$} & [0.634] & [0.635] & [0.614] & [0.617] & [0.639] & [0.679] & [0.639] & [0.648] & {$[0.677]$} \\
\hline \multirow[t]{2}{*}{ Trade openness (average over $[t-1 ; t+1]$ ) } & -0.004 & -0.006 & -0.003 & -0.001 & -0.001 & 0 & -0.007 & -0.005 & -0.005 & -0.004 \\
\hline & {$[0.006]$} & {$[0.007]$} & {$[0.006]$} & {$[0.006]$} & {$[0.006]$} & {$[0.006]$} & {$[0.007]$} & {$[0.007]$} & {$[0.007]$} & {$[0.007]$} \\
\hline \multirow[t]{2}{*}{ Real exchange rate change (average over $[t-1 ; t+1]$ ) } & -0.025 & 0.012 & 0.01 & -0.036 & -0.038 & -0.004 & 0.043 & 0.013 & 0.007 & 0.04 \\
\hline & {$[0.083]$} & {$[0.091]$} & [0.083] & [0.084] & [0.084] & [0.084] & {$[0.092]$} & {$[0.092]$} & {$[0.092]$} & {$[0.093]$} \\
\hline \multirow[t]{2}{*}{ Initial debt-to-GDP ratio (t) } & & $0.013^{* *}$ & & & & & 0.009 & $0.014 * *$ & $0.013 * *$ & $0.012^{*}$ \\
\hline & & {$[0.006]$} & & & & & {$[0.006]$} & {$[0.006]$} & {$[0.006]$} & {$[0.006]$} \\
\hline \multirow[t]{2}{*}{ Primary balance (average over $[t-1 ; t+1]$ ) } & & -0.092 & & & & & -0.054 & -0.071 & $-0.104 *$ & -0.049 \\
\hline & & [0.061] & & & & & {$[0.062]$} & [0.062] & {$[0.062]$} & [0.065] \\
\hline \multirow[t]{2}{*}{ Real GDP growth (average over $[t-1 ; t+1]$ ) } & & -0.032 & & & & & -0.045 & -0.028 & -0.03 & -0.04 \\
\hline & & {$[0.054]$} & & & & & [0.055] & {$[0.055]$} & {$[0.054]$} & {$[0.056]$} \\
\hline \multirow[t]{2}{*}{ Nominal interest rate (average over $[\mathrm{t}-1 ; \mathrm{t}+1]$ ) } & & -0.009 & & & & & -0.016 & -0.008 & 0 & -0.005 \\
\hline & & {$[0.020]$} & & & & & {$[0.020]$} & {$[0.020]$} & {$[0.021]$} & {$[0.021]$} \\
\hline \multirow[t]{2}{*}{ CPI inflation (average over $[t-1 ; t+1]$ ) } & & -0.001 & & & & & 0 & -0.002 & -0.007 & -0.006 \\
\hline & & [0.009] & & & & & {$[0.009]$} & [0.009] & {$[0.010]$} & {$[0.010]$} \\
\hline \multirow[t]{2}{*}{ Expansion coincided with house price bust } & & & $-0.986^{* * *}$ & & & $-0.883^{* * *}$ & $-0.996 * * *$ & & & $-0.860^{* *}$ \\
\hline & & & [0.317] & & & {$[0.324]$} & [0.348] & & & [0.352] \\
\hline \multirow[t]{2}{*}{ Expansion coincided with equity price bust } & & & & -0.389 & & -0.306 & & $-0.539 *$ & & -0.505 \\
\hline & & & & [0.285] & & {$[0.297]$} & & {$[0.304]$} & & [0.315] \\
\hline \multirow[t]{2}{*}{ Expansion coincided with credit bust } & & & & & $-0.556^{*}$ & -0.319 & & & $-0.691^{*}$ & -0.459 \\
\hline & & & & & {$[0.321]$} & {$[0.332]$} & & & {$[0.394]$} & [0.408] \\
\hline \multirow[t]{2}{*}{ Constant } & $-4.739 * * *$ & 0.266 & -1.473 & -1.914 & -1.921 & $-3.671^{* * *}$ & 0.594 & 0.12 & 0.233 & 0.149 \\
\hline & [1.109] & {$[3.012]$} & [1.928] & [1.922] & {$[1.937]$} & [1.153] & {$[3.101]$} & {$[2.927]$} & {$[3.066]$} & {$[3.074]$} \\
\hline Observations & 192 & 176 & 192 & 192 & 192 & 192 & 176 & 176 & 176 & 176 \\
\hline Weibul parameter $(p)$ & 1.94 & 2.117 & 2.012 & 1.945 & 1.961 & 2.021 & 2.185 & 2.134 & 2.138 & 2.207 \\
\hline \multicolumn{11}{|l|}{ B. Debt contractions } \\
\hline & (I) & (II) & (III) & (IV) & (V) & $(\mathrm{VI})$ & (VII) & (VIII) & $(\mathrm{IX})$ & $(\mathrm{X})$ \\
\hline \multirow[t]{2}{*}{ Dummy for Eurozone countries } & 1.007 & 0.226 & 0.804 & 1.017 & 0.979 & 0.812 & 0.116 & 0.291 & 0.215 & 0.147 \\
\hline & [0.764] & {$[0.851]$} & {$[0.777]$} & [0.768] & [0.767] & {$[0.778]$} & {$[0.865]$} & {$[0.866]$} & [0.852] & {$[0.885]$} \\
\hline \multirow[t]{2}{*}{ Trade openness (average over $[t-1 ; t+1]$ ) } & $-0.018^{* * *}$ & -0.011 & $-0.021^{* * *}$ & $-0.017^{* *}$ & $-0.019 * * *$ & $-0.019 * *$ & -0.013 & -0.009 & -0.012 & -0.01 \\
\hline & [0.007] & {$[0.009]$} & {$[0.007]$} & {$[0.008]$} & {$[0.007]$} & {$[0.008]$} & {$[0.009]$} & {$[0.009]$} & {$[0.009]$} & [0.009] \\
\hline \multirow[t]{2}{*}{ Real exchange rate change (average over $[t-1 ; t+1]$ ) } & 0.043 & 0.168 & 0.039 & 0.042 & 0.043 & 0.035 & 0.162 & 0.164 & 0.163 & 0.152 \\
\hline & {$[0.044]$} & {$[0.110]$} & {$[0.042]$} & [0.044] & {$[0.044]$} & [0.043] & {$[0.111]$} & [0.109] & {$[0.112]$} & [0.112] \\
\hline Initial debt-to-GDP ratio (t) & & $-0.013 * * *$ & & & & & $-0.014 * * *$ & $-0.013 * * *$ & $-0.013 * * *$ & $-0.014 * * *$ \\
\hline & & {$[0.005]$} & & & & & {$[0.005]$} & [0.005] & [0.005] & [0.005] \\
\hline Primary balance (average over $[t-1 ; t+1]$ ) & & $-0.131 * *$ & & & & & $-0.132 * *$ & $-0.133^{* *}$ & $-0.130 * *$ & $-0.138^{* *}$ \\
\hline & & [0.061] & & & & & [0.062] & [0.061] & [0.061] & [0.063] \\
\hline Real GDP growth (average over [t-1;t+1]) & & -0.06 & & & & & -0.064 & -0.067 & -0.058 & -0.079 \\
\hline & & [0.046] & & & & & [0.047] & [0.047] & [0.047] & [0.049] \\
\hline Nominal interest rate (average over $[\mathrm{t}-1 ; \mathrm{t}+1]$ ) & & 0.026 & & & & & 0.028 & 0.031 & 0.025 & 0.038 \\
\hline & & [0.027] & & & & & {$[0.028]$} & {$[0.028]$} & [0.027] & [0.029] \\
\hline CPI inflation (average over [t-1;t+1]) & & $0.014^{*}$ & & & & & $0.014^{*}$ & 0.013 & $0.014^{*}$ & 0.012 \\
\hline & & {$[0.008]$} & & & & & {$[0.008]$} & {$[0.008]$} & [0.008] & {$[0.008]$} \\
\hline Contraction coincided with house price boom & & & 0.350 & & & 0.404 & 0.244 & & & 0.389 \\
\hline & & & [0.257] & & & [0.281] & [0.279] & & & {$[0.316]$} \\
\hline Contraction coincided with equity price boom & & & & -0.042 & & -0.191 & & -0.229 & & -0.391 \\
\hline & & & & [0.273] & & [0.296] & & [0.307] & & [0.332] \\
\hline Contraction coincided with credit boom & & & & & 0.110 & 0.024 & & & 0.084 & -0.015 \\
\hline & & & & & {$[0.280]$} & {$[0.296]$} & & & {$[0.330]$} & {$[0.349]$} \\
\hline Constant & 3.958 & 2.169 & 4.789 & 3.764 & 4.165 & 4.052 & 2.675 & 1.571 & 2.215 & $-2.535^{* *}$ \\
\hline & [2.978] & [3.814] & [3.016] & [3.233] & [3.027] & [3.235] & [3.835] & [3.924] & [3.821] & [1.197] \\
\hline Observations & 184 & 166 & 184 & 184 & 184 & 184 & 166 & 166 & 166 & 166 \\
\hline Weibul parameter $(p)$ & 2.261 & 2.458 & 2.274 & 2.26 & 2.261 & 2.273 & 2.471 & 2.457 & 2.458 & 2.478 \\
\hline
\end{tabular}

Note: Duration regressions are performed using the Weibull model. All regressions include country fixed-effects. Robust standard errors are in brackets. *,**, and ${ }^{* * *}$ denote significance at the 10 percent, 5 percent, and 1 percent levels, respectively. The dependent variables are: (i) duration of debt expansion in panel A; and (ii) duration of debt contraction in panel B. Dummies for debt expansions coincided with financial (house price, equity price, and credit) busts take on a value of 1 if financial variables reached peak during $[t-1 ; t+1]$. Dummies for debt contractions coincided with financial (house price, equity price, and credit) booms take on a value of 1 if financial variables reached trough during $[t-1 ; t+1]$. $t$ refers to the year when debt expansions (contractions) have started. The Weibull parameter is significantly different from 1 in all specifications at 1 percent confidence level. 
Table 8. Robustness to Political Factors

\begin{tabular}{|c|c|c|c|c|c|c|c|c|c|c|}
\hline & (I) & (II) & (III) & (IV) & (V) & (VI) & (VII) & (VIII) & $(\mathrm{IX})$ & $(\mathrm{X})$ \\
\hline \multirow[t]{2}{*}{ PolitylV index (average over [t-1;t+1]) } & -0.012 & 0.133 & 0.072 & 0.118 & 0.082 & 0.205 & 0.155 & 0.242 & 0.207 & 0.299 \\
\hline & {$[0.216]$} & {$[0.246]$} & [0.219] & {$[0.224]$} & {$[0.220]$} & {$[0.233]$} & {$[0.252]$} & {$[0.250]$} & {$[0.251]$} & {$[0.265]$} \\
\hline \multirow[t]{2}{*}{ Initial debt-to-GDP ratio (t) } & & $0.010^{*}$ & & & & & 0.006 & $0.013^{* *}$ & $0.011^{* *}$ & $0.011^{*}$ \\
\hline & & [0.005] & & & & & {$[0.005]$} & {$[0.005]$} & {$[0.005]$} & {$[0.006]$} \\
\hline \multirow[t]{2}{*}{ Primary balance (average over $[t-1 ; t+1]$ ) } & & -0.074 & & & & & -0.03 & -0.037 & -0.08 & -0.01 \\
\hline & & [0.057] & & & & & {$[0.060]$} & [0.059] & [0.057] & {$[0.062]$} \\
\hline \multirow[t]{2}{*}{ Real GDP growth (average over $[t-1 ; t+1]$ ) } & & -0.029 & & & & & -0.055 & -0.027 & -0.03 & -0.048 \\
\hline & & [0.052] & & & & & [0.054] & {$[0.054]$} & [0.052] & {$[0.056]$} \\
\hline \multirow[t]{2}{*}{ Nominal interest rate (average over $[t-1 ; t+1]$ ) } & & 0.002 & & & & & -0.004 & 0.003 & 0.011 & 0.004 \\
\hline & & [0.018] & & & & & {$[0.018]$} & {$[0.018]$} & [0.019] & [0.019] \\
\hline \multirow[t]{2}{*}{ CPI inflation (average over $[t-1 ; t+1]$ ) } & & 0.014 & & & & & 0.011 & $0.017 *$ & 0.01 & 0.013 \\
\hline & & [0.009] & & & & & {$[0.009]$} & {$[0.009]$} & [0.010] & {$[0.010]$} \\
\hline \multirow{2}{*}{ Expansion coincided with house price bust } & & & $-1.222^{* * *}$ & & & $-1.027^{* * *}$ & $-1.172^{* * *}$ & & & $-0.986^{* * *}$ \\
\hline & & & [0.315] & & & {$[0.330]$} & [0.346] & & & [0.350] \\
\hline \multirow{2}{*}{ Expansion coincided with equity price bust } & & & & $-0.627^{* *}$ & & -0.402 & & $-0.837^{* * *}$ & & $-0.752 * *$ \\
\hline & & & & {$[0.279]$} & & [0.295] & & [0.302] & & [0.323] \\
\hline \multirow[t]{2}{*}{ Expansion coincided with credit bust } & & & & & $-0.767^{* *}$ & -0.412 & & & $-0.709 *$ & -0.389 \\
\hline & & & & & [0.324] & [0.344] & & & {$[0.383]$} & {$[0.405]$} \\
\hline \multirow[t]{2}{*}{ Constant } & -14.549 & -12.396 & $-6.242^{* * *}$ & -15.38 & -16.094 & -15.735 & -13.187 & $-5.449 * * *$ & $-5.096 * * *$ & -12.8 \\
\hline & [212.413] & [56.734] & [1.080] & [300.762] & [426.321] & [316.918] & [80.144] & [1.606] & [1.597] & [56.708] \\
\hline Observations & 190 & 172 & 190 & 190 & 190 & 190 & 172 & 172 & 172 & 172 \\
\hline Weibul parameter $(p)$ & 1.974 & 2.184 & 2.064 & 1.984 & 2.009 & 2.072 & 2.259 & 2.225 & 2.21 & 2.3 \\
\hline \multicolumn{11}{|l|}{ B. Debt contractions } \\
\hline & (I) & (II) & (III) & (IV) & (V) & $(\mathrm{VI})$ & (VII) & (VIII) & (IX) & $(\mathrm{X})$ \\
\hline \multirow[t]{2}{*}{ PolitylV index (average over [t-1;t+1]) } & $-0.528^{* *}$ & -0.09 & $-0.555 * *$ & $-0.475^{*}$ & $-0.550^{* *}$ & $-0.530 * *$ & -0.105 & -0.077 & -0.131 & -0.177 \\
\hline & {$[0.247]$} & {$[0.289]$} & {$[0.253]$} & {$[0.256]$} & {$[0.260]$} & {$[0.266]$} & {$[0.297]$} & {$[0.293]$} & {$[0.300]$} & {$[0.311]$} \\
\hline \multirow[t]{2}{*}{ Initial debt-to-GDP ratio (t) } & & $-0.017^{* * *}$ & & & & & $-0.017^{* * *}$ & $-0.016 * * *$ & $-0.017^{* * *}$ & $-0.016^{* * *}$ \\
\hline & & {$[0.005]$} & & & & & {$[0.005]$} & {$[0.005]$} & {$[0.005]$} & [0.005] \\
\hline \multirow[t]{2}{*}{ Primary balance (average over $[t-1 ; t+1]$ ) } & & $-0.106^{*}$ & & & & & $-0.105 *$ & $-0.110^{*}$ & $-0.103^{*}$ & $-0.106^{*}$ \\
\hline & & {$[0.058]$} & & & & & {$[0.058]$} & {$[0.058]$} & {$[0.057]$} & {$[0.057]$} \\
\hline \multirow[t]{2}{*}{ Real GDP growth (average over $[t-1 ; t+1]$ ) } & & -0.032 & & & & & -0.032 & -0.042 & -0.029 & -0.046 \\
\hline & & [0.043] & & & & & {$[0.044]$} & {$[0.044]$} & {$[0.044]$} & {$[0.046]$} \\
\hline \multirow[t]{2}{*}{ Nominal interest rate (average over $[\mathrm{t}-1 ; \mathrm{t}+1]$ ) } & & 0.017 & & & & & 0.017 & 0.023 & 0.013 & 0.019 \\
\hline & & [0.030] & & & & & {$[0.030]$} & [0.029] & [0.031] & {$[0.030]$} \\
\hline \multirow[t]{2}{*}{ CPI inflation (average over $[t-1 ; t+1]$ ) } & & $0.014^{*}$ & & & & & $0.014^{*}$ & 0.012 & $0.014^{*}$ & 0.011 \\
\hline & & [0.008] & & & & & {$[0.008]$} & {$[0.008]$} & {$[0.008]$} & [0.009] \\
\hline \multirow[t]{2}{*}{ Contraction coincided with house price boom } & & & 0.127 & & & 0.283 & 0.061 & & & 0.222 \\
\hline & & & [0.241] & & & [0.285] & {$[0.280]$} & & & [0.326] \\
\hline \multirow[t]{2}{*}{ Contraction coincided with equity price boom } & & & & -0.217 & & -0.406 & & -0.314 & & -0.480 \\
\hline & & & & [0.246] & & [0.295] & & [0.291] & & [0.333] \\
\hline \multirow[t]{2}{*}{ Contraction coincided with credit boom } & & & & & 0.080 & 0.142 & & & 0.197 & 0.272 \\
\hline & & & & & [0.285] & {$[0.315]$} & & & [0.344] & [0.365] \\
\hline Constant & $-3.144^{* * *}$ & $-3.460^{* * *}$ & $-3.125^{* * *}$ & $-3.407^{* * *}$ & $-3.127^{* * *}$ & $-3.454^{* * *}$ & $-3.461^{* * *}$ & $-3.429^{* * *}$ & $-3.489^{* * *}$ & $-3.469^{* * *}$ \\
\hline & [1.038] & [1.105] & [1.039] & [1.035] & [1.040] & [1.037] & [1.103] & [1.104] & [1.107] & [1.105] \\
\hline Observations & 186 & 163 & 186 & 186 & 186 & 186 & 163 & 163 & 163 & 163 \\
\hline Weibul parameter (p) & 2.216 & 2.432 & 2.218 & 2.218 & 2.216 & 2.224 & 2.434 & 2.434 & 2.436 & 2.447 \\
\hline
\end{tabular}

Note: Duration regressions are performed using the Weibull model. All regressions include country fixed-effects. Robust standard errors are in brackets. ${ }^{*}{ }^{* *}$, and ${ }^{* * *}$ denote significance at the 10 percent, 5 percent, and 1 percent levels, respectively. The dependent variables are: (i) duration of debt expansion in panel A, and (ii) duration of debt contraction in panel B. Dummies for debt expansions coincided with financial (house price, equity price, and credit) busts take on a value of 1 if financial variables reached peak during [t-1;t+1]. Dummies for debt contractions coincided with financial (house price, equity price, and credit) booms take on a value of 1 if financial variables reached trough during $[t-1 ; t+1]$. $t$ refers to the year when debt expansions (contractions) have started. The Weibull parameter is significantly different from 1 in all specifications at 1 percent confidence level. 
Table 9. Robustness to Banking Crises

\begin{tabular}{|c|c|c|c|c|c|c|c|c|c|c|}
\hline & (I) & (II) & (III) & (IV) & $(\mathrm{V})$ & $(\mathrm{VI})$ & (VII) & (VIII) & $(\mathrm{IX})$ & $(X)$ \\
\hline \multirow[t]{2}{*}{ Expansion preceeded by banking crisis (output loss) } & $0.632^{* *}$ & 0.418 & $0.731^{* *}$ & $0.686^{* *}$ & $0.611^{* *}$ & $0.737^{* *}$ & 0.504 & 0.491 & 0.466 & 0.572 \\
\hline & {$[0.280]$} & {$[0.373]$} & {$[0.293]$} & {$[0.286]$} & {$[0.306]$} & {$[0.303]$} & {$[0.391]$} & {$[0.377]$} & {$[0.392]$} & {$[0.407]$} \\
\hline \multirow[t]{2}{*}{ Initial debt-to-GDP ratio (t) } & & $0.011^{* *}$ & & & & & 0.008 & $0.013 * *$ & $0.012^{* *}$ & $0.011^{*}$ \\
\hline & & {$[0.005]$} & & & & & [0.006] & {$[0.005]$} & {$[0.006]$} & {$[0.006]$} \\
\hline \multirow[t]{2}{*}{ Primary balance (average over $[\mathrm{t}-1 ; \mathrm{t}+1]$ ) } & & -0.064 & & & & & -0.026 & -0.033 & -0.066 & -0.005 \\
\hline & & {$[0.055]$} & & & & & {$[0.056]$} & {$[0.057]$} & {$[0.053]$} & {$[0.060]$} \\
\hline \multirow[t]{2}{*}{ Real GDP growth (average over $[t-1 ; t+1]$ ) } & & -0.021 & & & & & -0.041 & -0.014 & -0.019 & -0.031 \\
\hline & & {$[0.051]$} & & & & & [0.055] & {$[0.054]$} & {$[0.051]$} & {$[0.057]$} \\
\hline \multirow[t]{2}{*}{ Nominal interest rate (average over $[\mathrm{t}-1 ; \mathrm{t}+1]$ ) } & & 0.007 & & & & & 0.001 & 0.009 & 0.015 & 0.01 \\
\hline & & {$[0.017]$} & & & & & {$[0.015]$} & {$[0.019]$} & {$[0.018]$} & [0.018] \\
\hline \multirow[t]{2}{*}{ CPI inflation (average over $[t-1 ; t+1]$ ) } & & 0.004 & & & & & 0.003 & 0.003 & -0.002 & -0.001 \\
\hline & & {$[0.007]$} & & & & & {$[0.007]$} & {$[0.009]$} & {$[0.008]$} & [0.009] \\
\hline \multirow[t]{2}{*}{ Expansion coincided with house price bust } & & & $-1.074 * * *$ & & & $-0.926 * *$ & $-1.006^{* *}$ & & & $-0.877^{* *}$ \\
\hline & & & [0.385] & & & [0.385] & [0.427] & & & [0.416] \\
\hline \multirow[t]{2}{*}{ Expansion coincided with equity price bust } & & & & -0.468 & & -0.245 & & $-0.591 *$ & & -0.5 \\
\hline & & & & {$[0.300]$} & & [0.319] & & {$[0.345]$} & & {$[0.377]$} \\
\hline \multirow[t]{2}{*}{ Expansion coincided with credit bust } & & & & & $-0.701 * *$ & -0.388 & & & -0.704 & -0.423 \\
\hline & & & & & [0.336] & [0.354] & & & [0.449] & [0.461] \\
\hline \multirow[t]{2}{*}{ Constant } & $-4.757^{* * *}$ & $-5.157^{* * *}$ & $-5.671^{* * *}$ & $-4.757^{* * *}$ & $-5.871^{* * *}$ & $-5.396 * * *$ & $-4.450^{* * *}$ & $-5.678^{* * *}$ & $-5.529 * * *$ & $-5.279 * * *$ \\
\hline & [0.689] & [1.282] & [0.462] & [0.682] & {$[0.466]$} & {$[0.480]$} & [1.372] & [1.244] & [1.323] & [1.404] \\
\hline Observations & 208 & 181 & 208 & 208 & 208 & 208 & 181 & 181 & 181 & 181 \\
\hline Weibul parameter $(p)$ & 1.985 & 2.125 & 2.059 & 1.984 & 2.009 & 2.061 & 2.19 & 2.139 & 2.146 & 2.208 \\
\hline \multicolumn{11}{|l|}{ B. Debt contractions } \\
\hline & (I) & (II) & (III) & (IV) & (V) & (VI) & (VII) & (VIII) & $(\mathrm{IX})$ & $(\mathrm{X})$ \\
\hline \multirow[t]{2}{*}{ Contraction preceeded by banking crisis (output loss) } & -0.14 & $0.947^{*}$ & -0.218 & 0.042 & -0.134 & -0.083 & 1.101 & $1.362^{* *}$ & 0.993* & $1.390^{*}$ \\
\hline & {$[0.315]$} & {$[0.572]$} & {$[0.376]$} & {$[0.376]$} & {$[0.359]$} & {$[0.415]$} & {$[0.685]$} & {$[0.683]$} & {$[0.586]$} & {$[0.732]$} \\
\hline \multirow[t]{2}{*}{ Initial debt-to-GDP ratio (t) } & & $-0.016^{* *}$ & & & & & $-0.015 * *$ & $-0.014 * *$ & $-0.016 * *$ & $-0.014^{* *}$ \\
\hline & & {$[0.006]$} & & & & & [0.006] & [0.006] & [0.006] & [0.006] \\
\hline \multirow[t]{2}{*}{ Primary balance (average over $[t-1 ; t+1]$ ) } & & $-0.142^{* *}$ & & & & & $-0.146 * *$ & $-0.159 * *$ & $-0.143 * *$ & $-0.160 * *$ \\
\hline & & {$[0.071]$} & & & & & {$[0.070]$} & [0.069] & {$[0.072]$} & {$[0.070]$} \\
\hline \multirow[t]{2}{*}{ Real GDP growth (average over $[t-1 ; t+1]$ ) } & & -0.015 & & & & & -0.011 & -0.025 & -0.017 & -0.026 \\
\hline & & [0.041] & & & & & {$[0.043]$} & {$[0.040]$} & {$[0.042]$} & {$[0.045]$} \\
\hline \multirow[t]{2}{*}{ Nominal interest rate (average over $[t-1 ; t+1]$ ) } & & 0.009 & & & & & 0.008 & 0.023 & 0.01 & 0.024 \\
\hline & & {$[0.027]$} & & & & & {$[0.026]$} & {$[0.026]$} & {$[0.028]$} & {$[0.028]$} \\
\hline \multirow[t]{2}{*}{$\mathrm{CPI}$ inflation (average over $[\mathrm{t}-1 ; \mathrm{t}+1]$ ) } & & 0.013 & & & & & 0.013 & 0.01 & 0.012 & 0.01 \\
\hline & & {$[0.010]$} & & & & & {$[0.010]$} & {$[0.010]$} & {$[0.010]$} & {$[0.010]$} \\
\hline \multirow[t]{2}{*}{ Contraction coincided with house price boom } & & & 0.123 & & & 0.261 & -0.190 & & & 0.001 \\
\hline & & & {$[0.256]$} & & & [0.283] & [0.323] & & & [0.393] \\
\hline \multirow[t]{2}{*}{ Contraction coincided with equity price boom } & & & & -0.322 & & -0.411 & & -0.610 & & -0.608 \\
\hline & & & & [0.283] & & [0.298] & & {$[0.380]$} & & [0.408] \\
\hline \multirow[t]{2}{*}{ Contraction coincided with credit boom } & & & & & -0.012 & 0.018 & & & -0.097 & -0.061 \\
\hline & & & & & [0.306] & [0.321] & & & [0.363] & [0.429] \\
\hline Constant & $-3.420 * * *$ & $-6.760 * * *$ & $-3.348 * * *$ & $-3.609 * * *$ & $-3.428 * * *$ & $-3.496 * * *$ & $-14.907 * * *$ & $-6.512^{* * *}$ & $-5.053 * * *$ & $-16.395^{* * *}$ \\
\hline & [0.344] & [1.423] & [0.394] & [0.401] & [0.392] & [0.439] & [1.498] & [1.485] & [0.849] & [1.538] \\
\hline Observations & 205 & 171 & 205 & 205 & 205 & 205 & 171 & 171 & 171 & 171 \\
\hline Weibul parameter (p) & 2.213 & 2.503 & 2.216 & 2.217 & 2.213 & 2.224 & 2.504 & 2.52 & 2.504 & 2.521 \\
\hline
\end{tabular}

Note: Duration regressions are performed using the Weibull model. All regressions include country fixed-effects. Robust standard errors are in brackets. *, **, and ${ }^{* * *}$ denote significance at the 10 percent, 5 percent, and 1 percent levels, respectively. The dependent variables are: (i) duration of debt expansion in panel $A$; and (ii) duration of debt contraction in panel B. Dummies for debt expansions coincided with financial (house price, equity price, and credit) busts take on a value of 1 if financial variables reached peak during $[t-1 ; t+1]$. Dummies for debt contractions coincided with financial (house price, equity price, and credit) booms take on a value of 1 if financial variables reached trough during $[t-1 ; t+1]$. t refers to the year when debt expansions (contractions) have started. The Weibull parameter is significantly different from 1 in all specifications at 1 percent confidence level. 
Table 10. Robustness to the Amplitude of Financial Cycles

\begin{tabular}{|c|c|c|c|c|c|c|}
\hline & (I) & (II) & (III) & (IV) & (V) & $(\mathrm{VI})$ \\
\hline \multirow[t]{2}{*}{ Initial debt-to-GDP ratio $(\mathrm{t})$} & & & & 0.009 & $0.023^{* * *}$ & $0.013^{* *}$ \\
\hline & & & & {$[0.006]$} & [0.006] & {$[0.006]$} \\
\hline \multirow[t]{2}{*}{ Primary balance (average over $[\mathrm{t}-1 ; \mathrm{t}+1]$ ) } & & & & 0.031 & 0.045 & -0.052 \\
\hline & & & & {$[0.068]$} & [0.067] & {$[0.055]$} \\
\hline \multirow[t]{2}{*}{ Real GDP growth (average over $[\mathrm{t}-1 ; \mathrm{t}+1]$ ) } & & & & -0.049 & -0.002 & $-0.096 *$ \\
\hline & & & & [0.058] & [0.064] & {$[0.058]$} \\
\hline \multirow[t]{2}{*}{ Nominal interest rate (average over $[t-1 ; t+1]$ ) } & & & & -0.009 & 0.002 & -0.003 \\
\hline & & & & [0.018] & [0.024] & [0.019] \\
\hline \multirow[t]{2}{*}{ CPI inflation (average over $[\mathrm{t}-1 ; \mathrm{t}+1]$ ) } & & & & 0.017 & $0.036 * * *$ & 0.004 \\
\hline & & & & [0.011] & [0.012] & [0.010] \\
\hline \multirow[t]{2}{*}{ Expansion coincided with house price bust } & $-1.505^{* * *}$ & & & $-1.585^{* * *}$ & & \\
\hline & {$[0.371]$} & & & [0.433] & & \\
\hline \multirow[t]{2}{*}{ Expansion coincided with equity price bust } & & $-1.244 * * *$ & & & $-1.801 * * *$ & \\
\hline & & [0.337] & & & [0.398] & \\
\hline \multirow{2}{*}{ Expansion coincided with credit bust } & & & $-0.612 *$ & & & -0.453 \\
\hline & & & {$[0.324]$} & & & [0.369] \\
\hline \multirow[t]{2}{*}{ Constant } & $-5.674 * * *$ & $-5.743^{* * *}$ & $-5.296 * * *$ & $-7.461 * * *$ & $-8.898 * * *$ & $-6.361 * * *$ \\
\hline & [1.056] & [1.060] & [1.043] & [1.282] & [1.383] & [1.226] \\
\hline Observations & 179 & 175 & 197 & 154 & 149 & 171 \\
\hline Weibul parameter $(\mathrm{p})$ & 2.158 & 2.187 & 1.995 & 2.446 & 2.636 & 2.197 \\
\hline \multicolumn{7}{|l|}{ B. Debt contractions } \\
\hline & $(\mathrm{I})$ & (II) & (III) & (IV) & $(\mathrm{V})$ & $(\mathrm{VI})$ \\
\hline \multirow[t]{2}{*}{ Initial debt-to-GDP ratio (t) } & & & & $-0.015^{*}$ & $-0.018^{*}$ & $-0.014^{* *}$ \\
\hline & & & & [0.008] & {$[0.010]$} & [0.006] \\
\hline \multirow[t]{2}{*}{ Primary balance (average over $[\mathrm{t}-1 ; \mathrm{t}+1]$ ) } & & & & $-0.259 * * *$ & -0.173 & -0.121 \\
\hline & & & & [0.089] & {$[0.139]$} & [0.080] \\
\hline \multirow[t]{2}{*}{ Real GDP growth (average over $[t-1 ; t+1]$ ) } & & & & 0.033 & -0.055 & -0.025 \\
\hline & & & & [0.071] & {$[0.042]$} & [0.043] \\
\hline \multirow[t]{2}{*}{ Nominal interest rate (average over $[t-1 ; t+1]$ ) } & & & & 0.045 & -0.002 & 0.028 \\
\hline & & & & [0.028] & [0.084] & [0.035] \\
\hline \multirow{2}{*}{ CPI inflation (average over $[\mathrm{t}-1 ; \mathrm{t}+1]$ ) } & & & & 0.011 & 0.021 & 0.011 \\
\hline & & & & {$[0.010]$} & {$[0.021]$} & [0.011] \\
\hline \multirow[t]{2}{*}{ Contraction coincided with house price boom } & 0.202 & & & 0.505 & & \\
\hline & {$[0.276]$} & & & {$[0.454]$} & & \\
\hline \multirow[t]{2}{*}{ Contraction coincided with equity price boom } & & -0.501 & & & -0.742 & \\
\hline & & {$[0.376]$} & & & {$[0.641]$} & \\
\hline \multirow{2}{*}{ Contraction coincided with credit boom } & & & -0.149 & & & 0.133 \\
\hline & & & [0.304] & & & [0.427] \\
\hline \multirow[t]{2}{*}{ Constant } & $-3.638 * * *$ & $-3.649 * * *$ & $-3.538^{* * *}$ & $-5.044 * * *$ & $-4.076^{* * *}$ & $-4.163 * * *$ \\
\hline & [0.188] & [0.217] & [0.175] & [0.716] & [1.026] & [0.542] \\
\hline Observations & 178 & 166 & 198 & 144 & 132 & 164 \\
\hline Weibul parameter $(p)$ & 2.261 & 2.267 & 2.198 & 2.653 & 2.608 & 2.418 \\
\hline
\end{tabular}

Note: Duration regressions are performed using the Weibull model. All regressions include country fixed-effects. Robust standard errors are in brackets. ${ }^{*},{ }^{* *}$, and ${ }^{* * *}$ denote significance at the 10 percent, 5 percent, and 1 percent levels, respectively. The dependent variables are: (i) duration of debt expansion in panel A; and (ii) duration of debt contraction in panel B. Dummies for debt expansions coincided with financial (house price, equity price, and credit) busts take on a value of 1 if financial variables reached peak during [t-1;t+1]. Dummies for debt contractions coincided with financial (house price, equity price, and credit) booms take on a value of 1 if financial variables reached trough during $[t-1 ; t+1]$. $t$ refers to the year when debt expansions (contractions) have started. The Weibull parameter is significantly different from 1 in all specifications at 1 percent confidence level. The sample is restricted to deviations of financial variables from their fundamental value below (above) their respective means during peaks (troughs). 
Figure 1. Length of the Cycles and their Amplitude
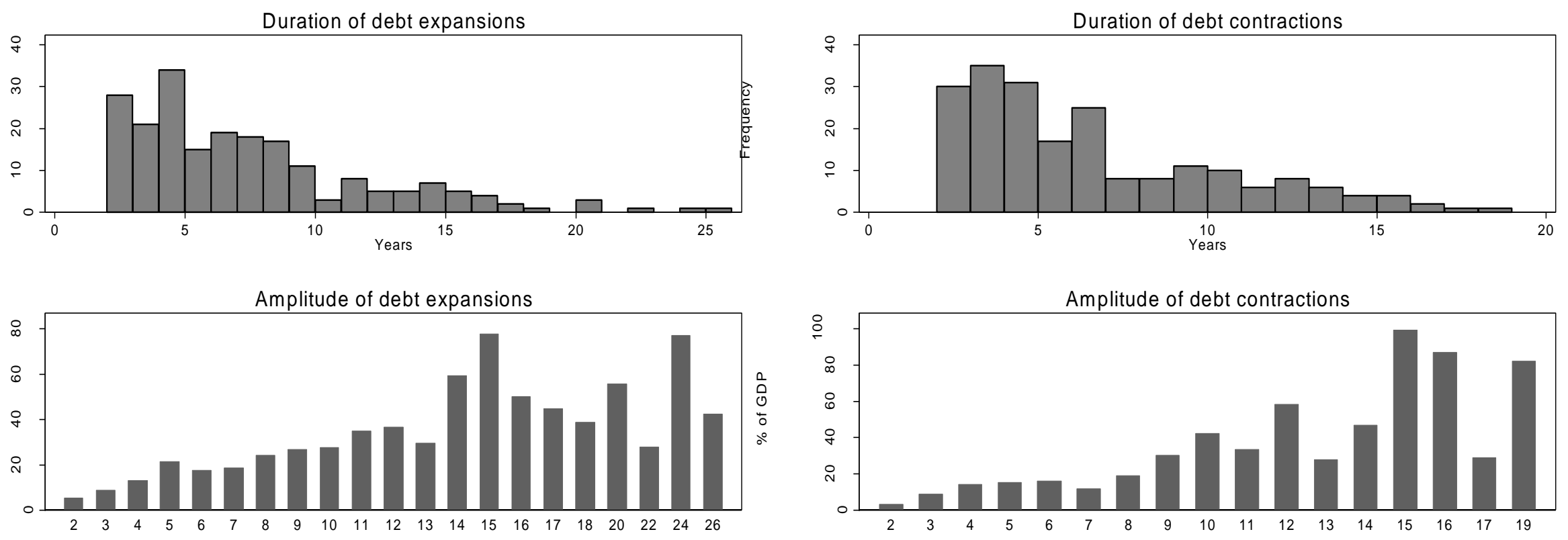

Note: Own estimations. 
Figure 2. Dynamics of Debt and its Determinants around Expansion Episodes
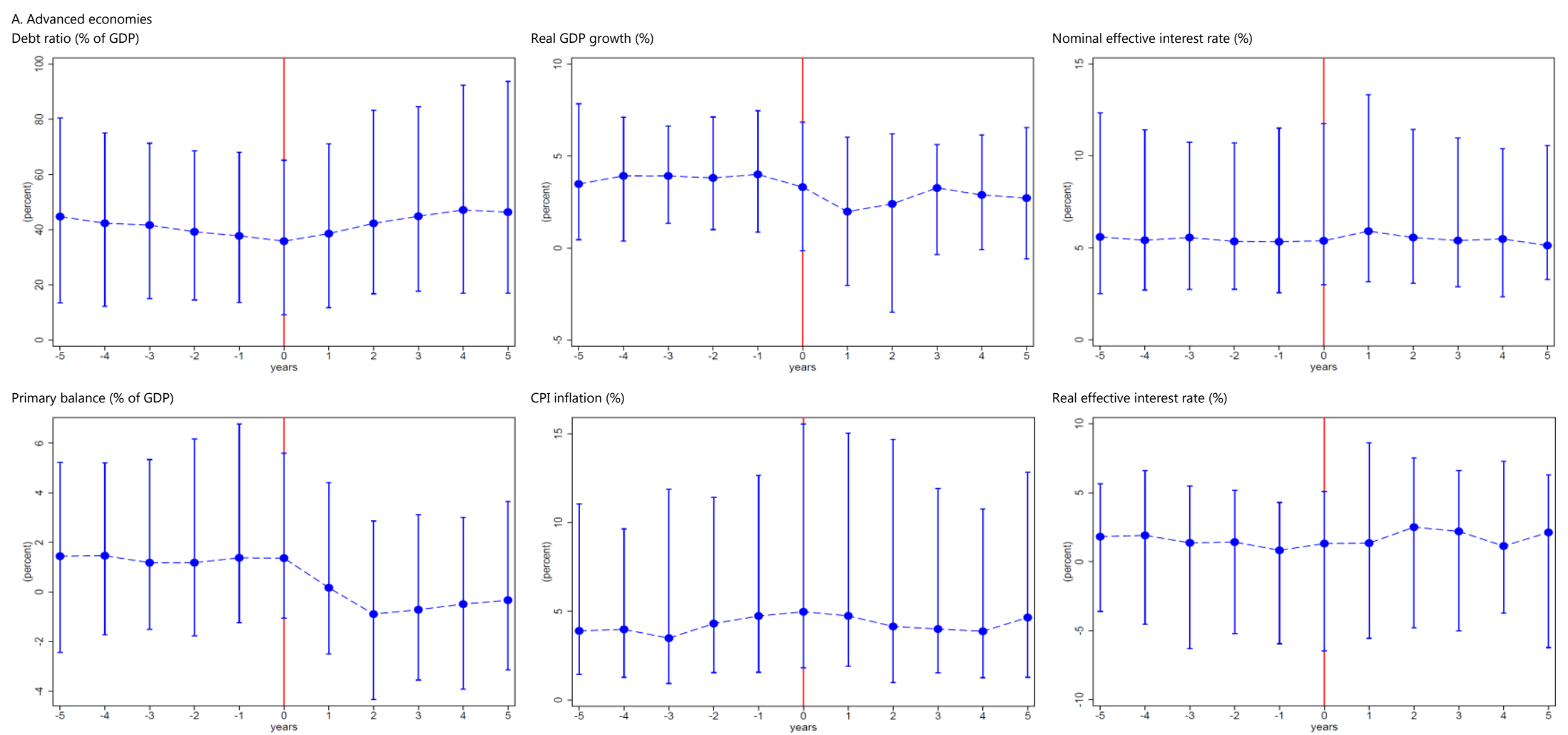

Note: Reported are medians and 10th/90th percentiles. $t=1$ is the first year of debt expansion. 
Figure 2 (cont-ed). Dynamics of Debt and its Determinants around Expansion Episodes
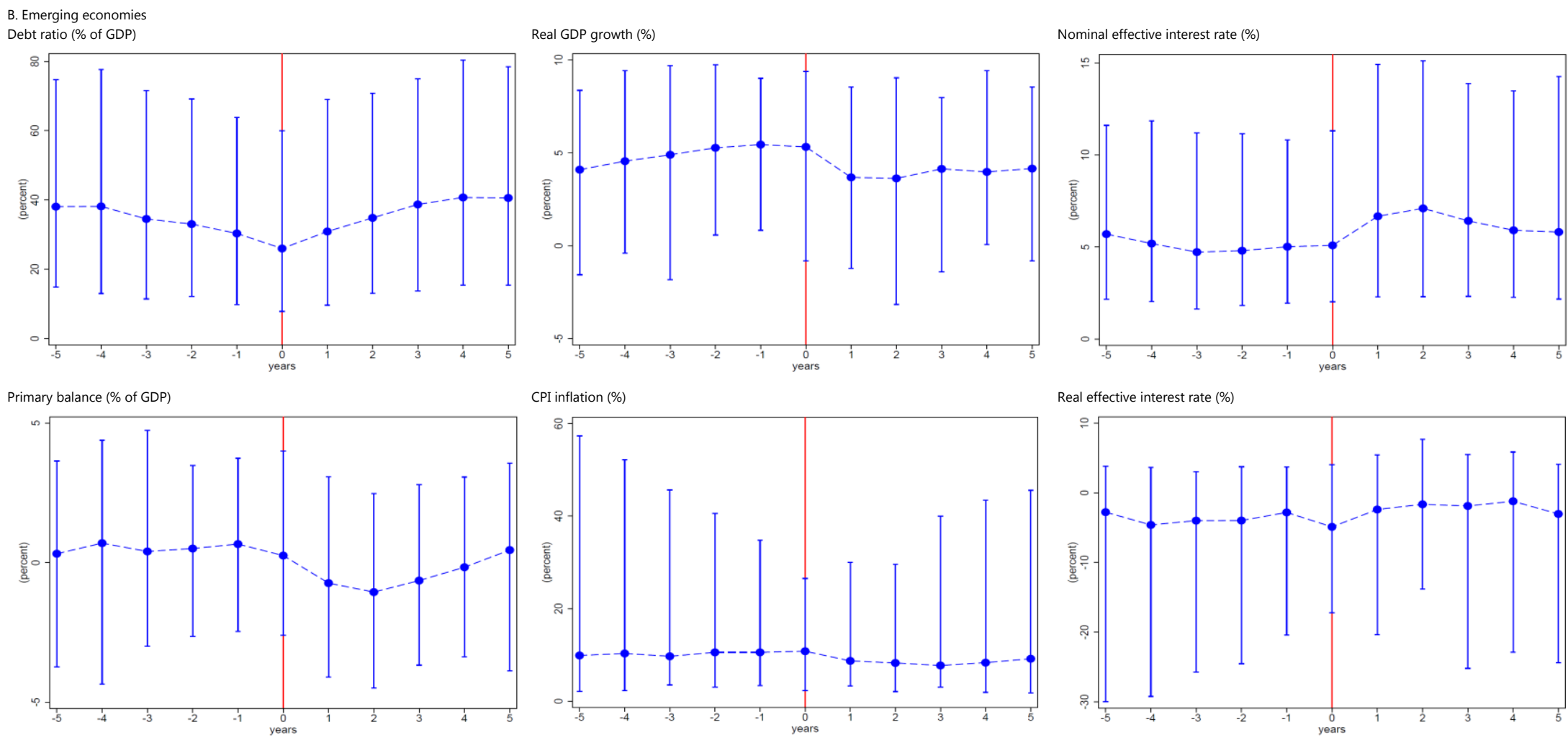

Note: Reported are medians and 10th/90th percentiles. $t=1$ is the first year of debt expansion. 
Figure 3. Dynamics of Debt and its Determinants around Contraction Episodes
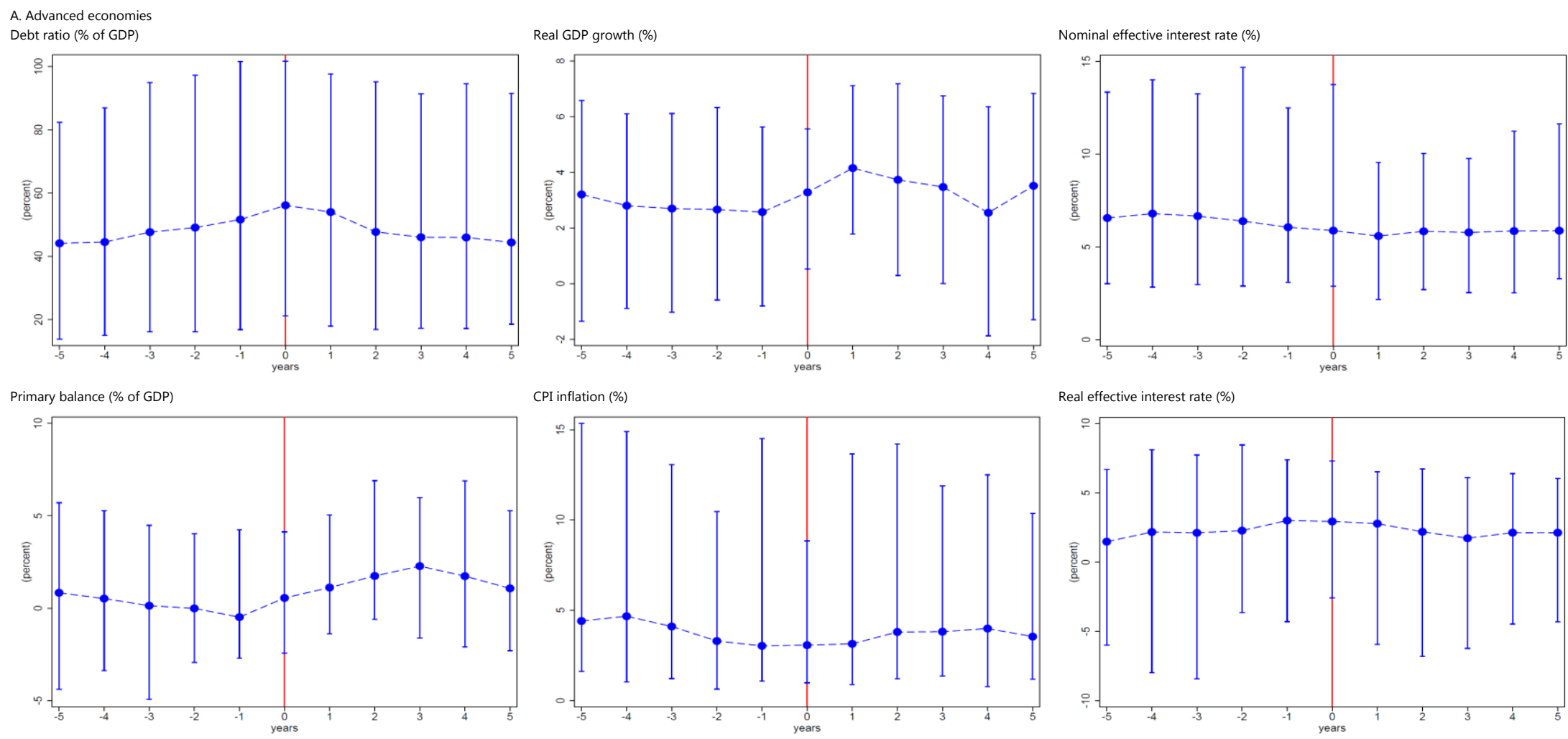

Note: Reported are medians and 10th/90th percentiles. $t=1$ is the first year of debt contraction. 
Figure 3 (cont-ed). Dynamics of Debt and its Determinants around Contraction Episodes
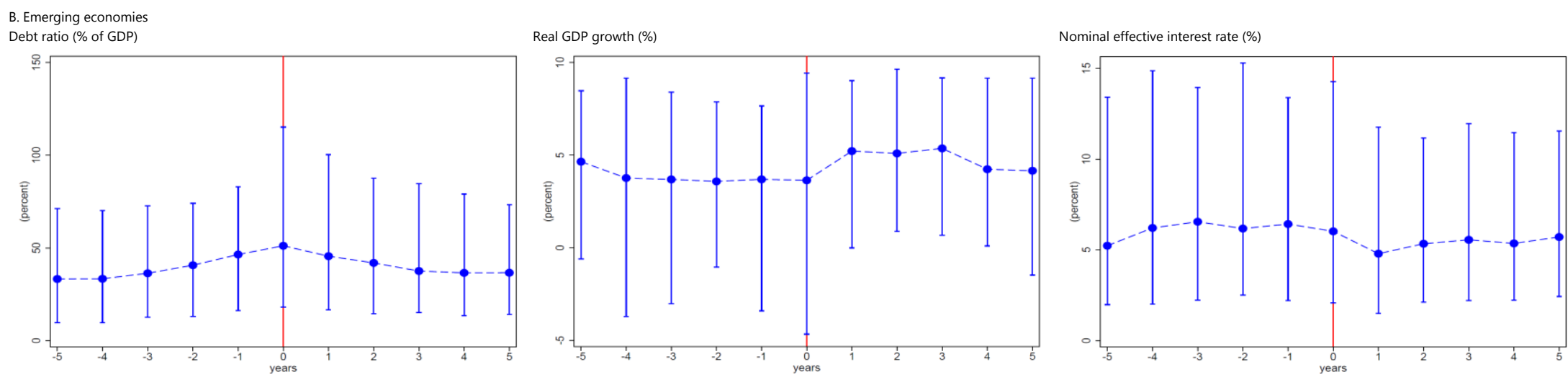

Primary balance (\% of GDP)
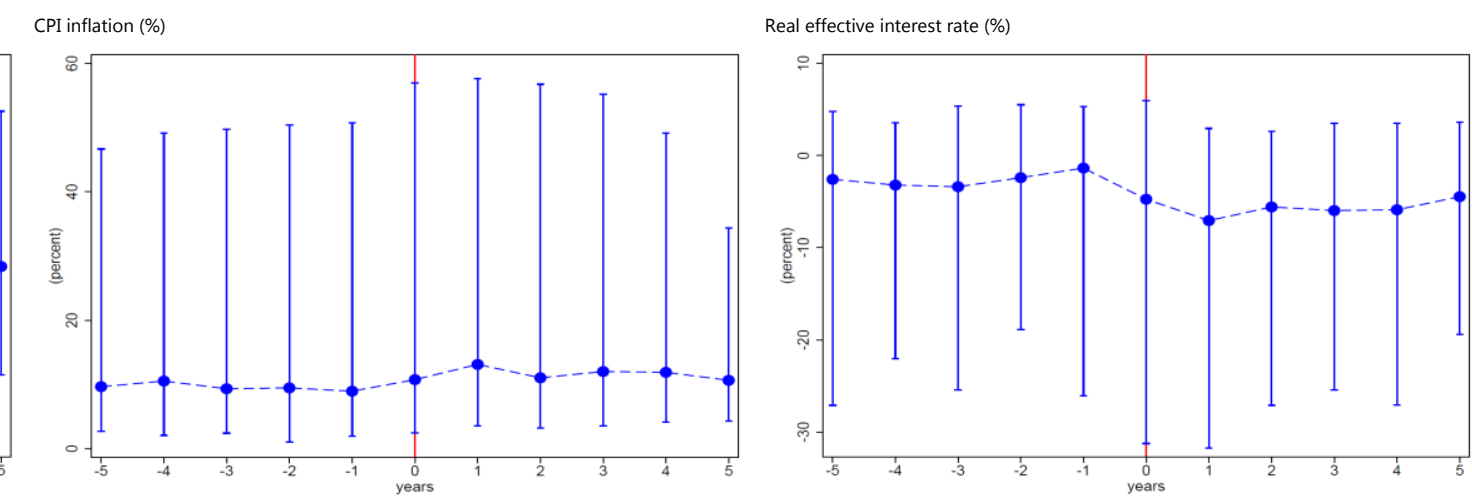

Note: Reported are medians and 10th/90th percentiles. $t=1$ is the first year of debt contraction. 
Figure 4. Non-Parametric Impact of Financial Cycles on the Duration of Debt Expansions and Contractions
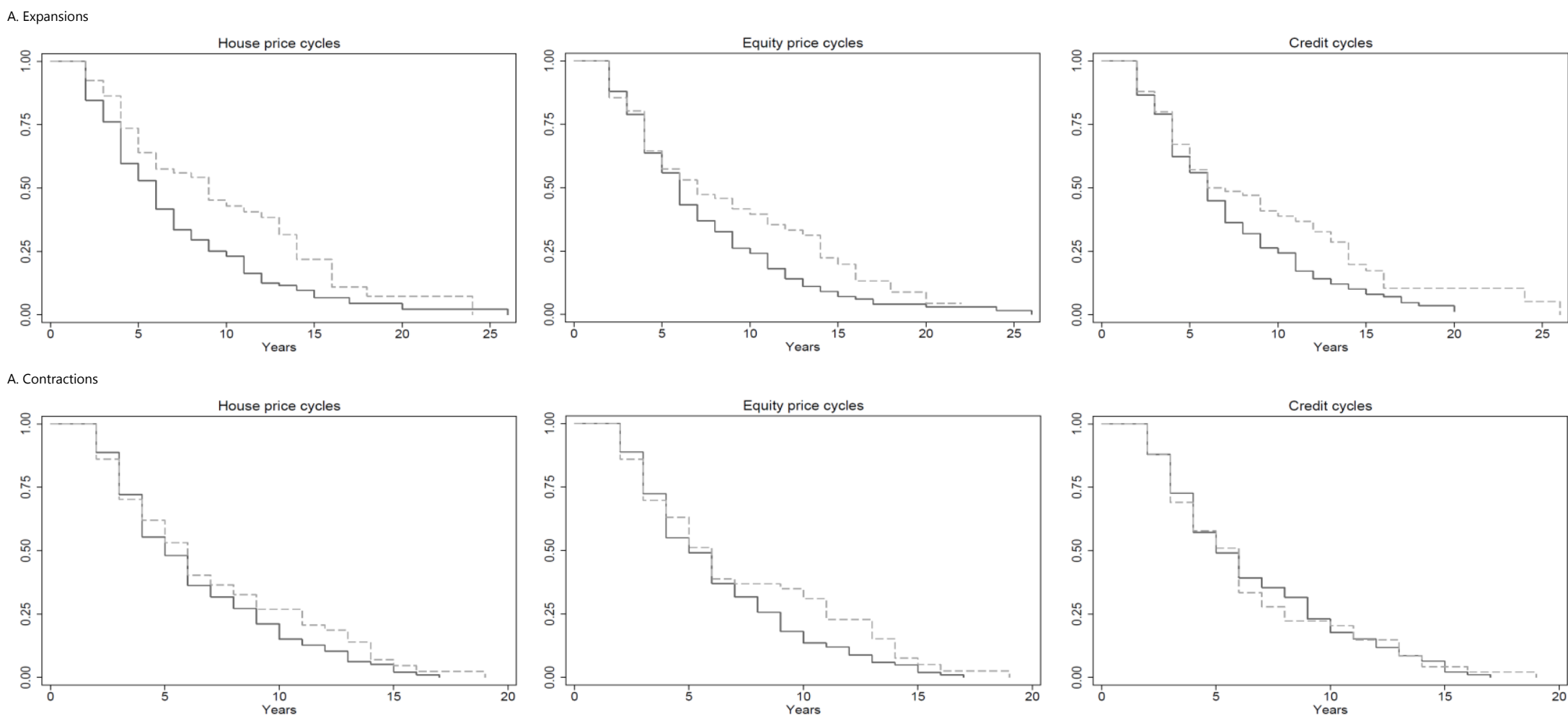

Note: Reported are Kaplan-Meier survival functions for debt expansions (Panel A) and contractions (Panel B). The dashed line represents expansions preceded by a peak in house price, equity price, and credit cycles, and contractions preceded by troughs in house price, equity price, and credit cycles. The solid line represents expansions (contractions) not preceded by peaks (troughs) in financial cycles. 